\title{
Analysis of the Prehistoric Caddo Ceramics from 41LR351, Lamar County, Texas
}

Timothy K. Perttula

Heritage Research Center, Stephen F. Austin State University

Follow this and additional works at: https://scholarworks.sfasu.edu/ita

Part of the American Material Culture Commons, Archaeological Anthropology Commons, Environmental Studies Commons, Other American Studies Commons, Other Arts and Humanities Commons, Other History of Art, Architecture, and Archaeology Commons, and the United States History Commons

Tell us how this article helped you.

This Article is brought to you for free and open access by the Center for Regional Heritage Research at SFA ScholarWorks. It has been accepted for inclusion in Index of Texas Archaeology: Open Access Gray Literature from the Lone Star State by an authorized editor of SFA ScholarWorks. For more information, please contact cdsscholarworks@sfasu.edu. 


\section{Analysis of the Prehistoric Caddo Ceramics from 41LR351, Lamar County, Texas \\ Creative Commons License \\ (c) () () (9)}

This work is licensed under a Creative Commons Attribution-NonCommercial 4.0 International License 


\title{
Analysis of the Prehistoric Caddo Ceramics from 41LR351, Lamar County, Texas
}

\author{
Timothy K. Perttula
}

\section{INTRODUCTION}

Site 41LR351 was first recorded during the 2005 Texas Archeological Society summer field school on the Stallings Ranch in Lamar County, Texas. This prehistoric site is on a natural knoll (420-430 feet amsl) in the headwaters of Pine Creek, a northward-flowing tributary of the Red River. The site is currently being excavated by the Valley of the Caddo Archeological Society, and a large prehistoric Caddo ceramic assemblage has been recovered that warrants study. In addition to characterizing the assemblage of vessel sherds in terms of decorative style and various technological attributes (i.e., temper and paste, firing conditions, surface treatment, etc.), I am also concerned with establishing the temporal and cultural affiliation of the recovered ceramics from 41LR351.

\section{ASSEMBLAGE AND PROVENIENCE INFORMATION}

The ceramic sherd assemblage from the excavation of 11 units at 41LR351 includes 598 plain and decorated sherds (Table 1). The decorated sherds comprise $19.6 \%$ of the assemblage. The highest densities of ceramic sherds are in N98-E54, N99E54, N100-E52, and N99-E58, with between 74-157 sherds per unit.

The plain to decorated sherd ratio (P/DR) is 4.1:1 at 41LR351. By way of comparison, the P/DR at the Stallings site (41LR297), across a small tributary to Pine Creek from 41LR351, is 14.3:1 (Perttula 2008a; see also Bruseth et al. 2009:Figure 1). The high $P / D R$ ratio at the Stallings site indicates that the assemblage in this pre-A.D. 1150 Caddo occupation was dominated by plain ware vessels and vessels with decoration confined almost exclusively to a small portion of the upper part of the vessel, but this tendency had changed by the time 41LR351 was occupied, which was apparently sometime after ca. A.D. 1100.

Pre-A.D. 1200 Caddo sites in the lower Red, middle Sabine, and Neches-Angelina River basins have P/DR values between 2.97-4.80:1 (Perttula 2004:390; Bruseth and Perttula 2006). Closer to 41LR351, at the Ray site (41LR135), thought to have been principally occupied between ca. A.D. 800-1000 by Bruseth et al. (2001:212), the P/DR value is 56.6:1. At the slightly later prehistoric Caddo component (ca. A.D. 1000-1250) at the Sam Kaufman/Roitsch site (41RR16) on the middle reaches of the Red River-specifically the East Mound excavations - the P/DR in the ceramic assemblage is 4.86:1 (Skinner et al. 1969:Tables 5 and 6), almost the same as 41LR351.

\section{METHODS OF ANALYSIS}

Detailed analysis of the decorated and plain ceramic sherds from 41LR351 (Appendix 1) is based on differences in temper, type of sherd (i.e., rim, body, or base), rim and lip form (cf. Brown 1996: Figure 2-12), decoration (if present), surface treatment (smoothing, burnishing, or polishing; see Rice 1987), and firing conditions (cf. Teltser 1993). Sherd cross-sections were inspected macroscopically and with a 10X hand lens to determine the character of the paste and its inclusions. Determining the firing conditions is based on the identification of the firing core in the sherd cross-sections and the identification of oxidation patterns as defined in Teltser (1993:535-536 and Figure 2a-h).

More specifically, the following attributes were employed in the analysis of the vessel ceramics: (a) temper, the deliberate and indeterminate materials found in the paste (Rice 1987:411), including a variety of tempers (grog or crushed sherds, burned bone, hematite, and burned mussel shell) and "particulate matters of some size;" (b) although most of the 
Table 1. Ceramic sherd assemblage from 41LR351.

\begin{tabular}{lccc}
\hline $\begin{array}{l}\text { Provenience } \\
\text { (N-E) }\end{array}$ & $\begin{array}{c}\text { No. of Plain } \\
\text { Sherds }\end{array}$ & $\begin{array}{c}\text { No. of Decorated } \\
\text { Sherds }\end{array}$ & $\mathrm{N}$ \\
\hline $95-55$ & 43 & 9 & 52 \\
$96-55$ & 10 & - & 10 \\
$97-60$ & 12 & - & 12 \\
$98-54$ & 123 & 34 & 157 \\
$98-59$ & 24 & 7 & 31 \\
$99-54$ & 71 & 29 & 100 \\
$99-58$ & 61 & 13 & 74 \\
$100-51$ & 49 & 11 & 60 \\
$100-52$ & 67 & - & 75 \\
$100-57$ & 2 & 6 & 2 \\
$101-53$ & 19 & 117 & 598 \\
\hline Totals & 481 & &
\end{tabular}

slipping, incising, punctating, and appliqued, and on certain sherds, combinations of decorative techniques (i.e., incised-punctated) created the decorative elements and motifs. Engraving was done with a sharp tool when the vessel was either leather-hard or after it was fired, while the other decorative techniques were executed with tools (incising or punctating with wood or bone sticks or dowels) or fingers (fingernail punctating and the creation of appliqued strips) when the vessel was wet or still plastic.

\section{DECORATED SHERDS}

The decorated sherds from 41LR351 are represented by 37

sherds are small and thus from indeterminate vessel forms, where sherds were large enough, vessel form categories include open containers (bowls and carinated bowls) and restricted containers, including jars and bottles. Other form attributes include rim profile (outflaring or everted, direct or vertical, and inverted) and lip profile (rounded, flat, or folded to the exterior). Base shape was recorded if possible. Observations on ceramic sherd cross-sections permit consideration of oxidation patterns (Teltser 1993:Figure 2), namely the conditions under which a vessel was fired and then cooled after firing. Finally, wall thickness was recorded in millimeters $(\mathrm{mm})$, using a vernier caliper, along the mid-section of the sherd.

With respect to interior and exterior surface treatment on the sherds, the primary methods of finishing the surface of the vessels includes smoothing and burnishing, and polishing, although a few sherds may still have scraping marks from initial surface treatment work by the potter. Smoothing creates "a finer and more regular surface... [and] has a matte rather than a lustrous surface" (Rice 1987:138). Burnishing creates an irregular lustrous finish marked by parallel facets left by the burnishing tool (perhaps a smoothed pebble or bone). A polished surface treatment is marked by a uniform and highly lustrous surface finish, done when the vessel is dry, but without "the pronounced parallel facets produced by burnishing leather-hard clay" (Rice 1987:138).

Decorative techniques present in the 41LR351 ceramic sherd collection include engraving, rims and 80 body sherds. The decorated sherds are readily separated into fine wares $(n=51,43.6 \%$ of the decorated sherds) or utility wares $(n=66,56.4 \%$ of the decorated sherds), following the distinctions discussed by Schambach and Miller (1984) at the Cedar Grove site in the Great Bend area in southwestern Arkansas. These distinctions include apparent differences in temper, surface treatment, vessel forms, and decorative methods between the two wares. Utility wares generally are jars and simple bowls used for the cooking and storage of foods, have a coarse temper, and lack burnishing, polishing, or slipping on interior and exterior vessel sherd surfaces. Such vessel sherds are decorated with brushing, incising, punctations (tool, cane, or fingernail), and appliqued elements, either by themselves or in combination with one or more of these decorative methods (see Perttula et al. 1995; Schambach and Miller 1984; Suhm and Jelks 1962). Fine wares, on the other hand, consist principally of engraved and slipped vessel sherds from carinated bowls, some simple bowls, and bottles. The fine ware vessel sherds more frequently are smoothed or burnished on the exterior vessel surface, and as will be discussed in more detail below, the fine ware vessels from 41LR351 were made, fired, and used in different ways than were the utility ware vessels.

The fine ware sherds from 41LR351 include 11 rim and 40 body sherds that have engraved and/or red-slipped decorations (Table 2). More than $90 \%$ of the rim sherds are from engraved vessels, including 
Table 2. Decorated fine ware sherds from 41LR351.

\begin{tabular}{lccc}
\hline Decorative elements & Rim & Body & $\%$ RS \\
\hline Engraved & & & - \\
parallel engraved lines & - & 7 & 20.0 \\
diagonal engraved lines & 2 & 3 & 75.0 \\
diagonal-horizontal engraved lines & 3 & 1 & - \\
vertical-diagonal engraved lines & 1 & 1 & - \\
opposed diagonal engraved lines & 1 & - & - \\
cross-hatched engraved lines & - & 1 & - \\
horizontal engraved lines & 3 & 2 & 42.9 \\
int. horizontal engraved lines & - & 1 & 33.3 \\
single straight engraved line & - & 7 & \\
$\quad$ Subtotal & 10 & 23 & 100.0 \\
$\quad$ Red-slipped & & & 100.0 \\
int./ext. red-slipped & 1 & 12 & 100.0 \\
ext. red-slipped & - & 5 & 56.9 \\
\hline \multicolumn{1}{c}{ Subtotal } & 1 & 17 & \\
\hline
\end{tabular}

RS=red-slipped

carinated bowls and compound bowls. There are also body sherds represented in the fine wares from the site. In addition to the 18 red-slipped sherds that may be from plain slipped vessels (bottles and carinated bowls) as well as from the undecorated portions of slipped vessels, $33.3 \%$ of the engraved sherds are from vessels that have also been red-slipped (Table 2). Approximately $55 \%$ of the fine ware sherds from 41LR351 have a red slip on either one or both vessel surfaces.

The engraved sherds have simple geometric decorative elements composed of horizontal, parallel (where the sherd orientation is not known) diagonal, opposed diagonal, vertical-diagonal, or cross-hatched lines (Figures 1a-e and 2a-d and Table 2). The decorative elements are confined to the rim of carinated bowls, compound bowls, and probably simple bowls.

Two sherds from 411R351 compare favorably to decorative elements on Holly Fine Engraved vessels (see Suhm and Jelks 1962:Plates 39 and 40) in that they have closely spaced sets of vertical and diagonal engraved lines on a vessel rim (see Figures $1 b-c$ and Figure 2a). Where they differ from classic examples of Holly Fine Engraved is in the absence of excised triangles (Suhm and Jelks 1962:77) as an integral attribute of the motif, as well as the fact that the engraved lines are not finely executed. According to Story (2000), Holly Fine Engraved vessels were likely manufactured between ca. A.D. 850-1300 in various locales across Northeast Texas.

The other engraved sherds (see Figures 1a, d-e and 2b-d and Table 2), many of which are redslipped, are likely from Sanders Engraved vessels (see Brown 1996:403-404 and Figures 2-38a, c, e and 2-39a-c, i, m; Krieger 1946:Plate 27, 2000:139, 142-143; Suhm and Jelks 1962:137 and Plate 69). Suhm and Jelks (1962:137) describe the decorative elements on Sanders Engraved vessels as "very simple straight-line motifs in a single zone around rims...the designs may consist only of parallel lines pitched in opposite directions at intervals... groups of vertical lines at intervals... and a continuous series of triangles filled with hachuring or crosshatching."

The red-slipped sherds comprise $35 \%$ of the fine wares from 41LR351. If these sherds are from vessels that are decorated only with red-slipping on either one or both vessel surfaces, then they can be 


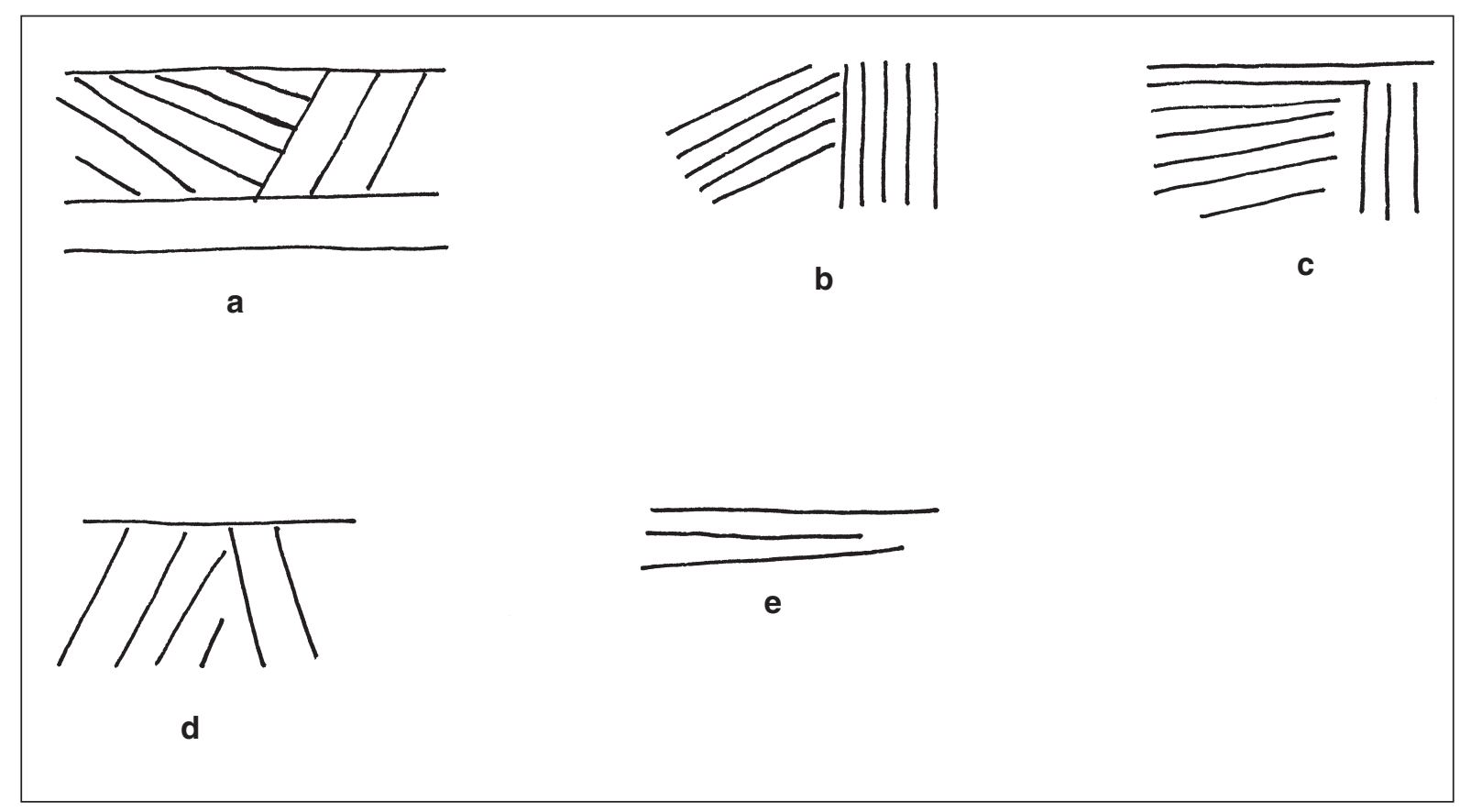

Figure 1. Selected fine ware decorative elements: a, horizontal and diagonal opposed engraved rim; $b$, vertical and diagonal engraved lines, cf. Holly Fine Engraved; c, horizontal-vertical-diagonal engraved rim; d, opposed diagonal engraved rim; e, horizontal and diagonal engraved/red-slipped rim. Provenience: a, N99 E54 (Lot 134); b, N98 E54, lv. 6 (Lot 137); c, N95 E55, lv. 8 (Lot 160); d, N100 E52, lv. 6 (Lot 138); e, N98 E54, lv. 4 (Lot 130).

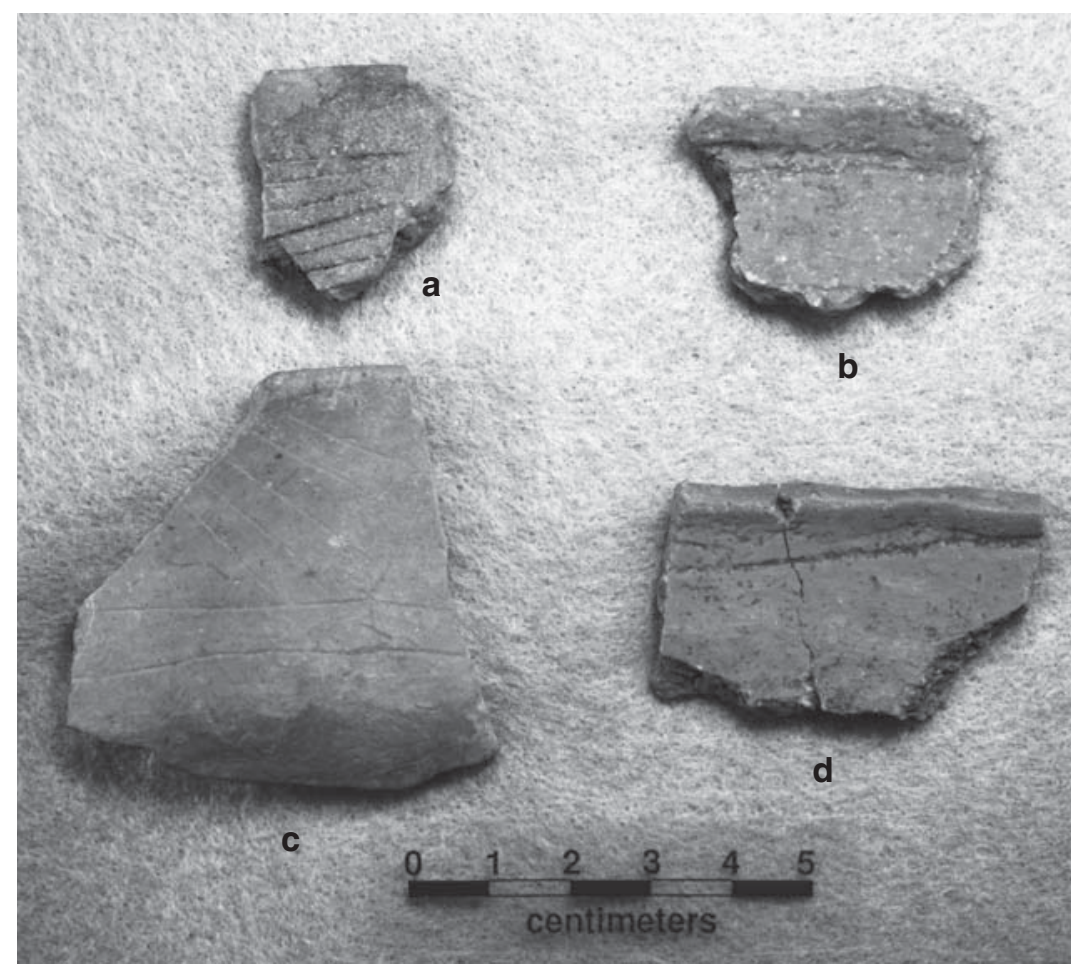

Figure 2. Engraved sherds from 41LR351: top row, left to right: a, horizontalvertical-diagonal engraved rim (N98 E59); b, horizontal engraved and red-slipped rim (N98 E59); bottom row, left to right, c, horizontal and diagonal opposed engraved rim (N99 E54, Lot 134); d, horizontal and diagonal engraved and redslipped rim (N98 E54, Lot 130). 
classified as Sanders Plain (Suhm and Jelks 1962:139 and Plate 70; see also Krieger 1946:Plates 24-26). According to Brown (1996:401), Sanders Plain is "a grog tempered slipped and undecorated ceramic."

The majority of the decorated utility ware sherds from 41LR351 have incised decorative elements (Table 3 and Figures 3b, d, f and 4a-g). The incised sherds comprise $68 \%$ of the decorated utility wares, including $69 \%$ of the utility ware rim sherds. Other utility wares include rim and body sherds with various punctated elements $(18 \%)$, sherds with incised-punctated designs (12\%, Figure 3a, c, e), and one sherd $(1.5 \%)$ with a simple appliqued design.

The incised sherds (see Figures 3b, d, f and Fig- ure 4a-g), and many of the incised-punctated sherds, are from Canton Incised vessels that have "parallel diagonal lines around rim, all in the same direction... alternating in direction....alternating with intervening spaces filled with small punctations or fingernail marks... nested together in hachures... or crossed in a diagonal grid" (Suhm and Jelks 1962:23; see also Krieger 1946:Plate 28f-g). At 41LR351, the most common decorative elements (based on 15 rim sherds) feature sets of diagonal incised or cross-hatched incised lines. The two rims with tool punctate-filled incised triangles (see Figure 3c, e and Figure 5a) are also from Canton Incised vessels.

There are three incised-punctated sherds from

Table 3. Decorated utility ware sherds from 41LR351.

\begin{tabular}{|c|c|c|}
\hline Decorative elements & Rim & Body \\
\hline diagonal incised lines & 7 & 2 \\
\hline diagonal opposed incised lines & - & 3 \\
\hline opposed incised lines & 1 & - \\
\hline cross-hatched incised lines & 8 & 6 \\
\hline parallel incised lines & - & 10 \\
\hline vertical incised lines & 1 & 2 \\
\hline vertical-horizontal incised lines & - & 1 \\
\hline vertical-diagonal incised lines & 1 & - \\
\hline horizontal-diagonal incised lines & - & 1 \\
\hline straight incised line & - & 2 \\
\hline subtotal & 18 & 27 \\
\hline tool punctated rows & 1 & 2 \\
\hline tool punctates, free & 1 & - \\
\hline fingernail punctated rows & 2 & 1 \\
\hline cane punctated rows & 1 & 1 \\
\hline large circular punctated rows & 1 & - \\
\hline linear punctated rows & - & 1 \\
\hline free punctates & - & 1 \\
\hline subtotal & 6 & 6 \\
\hline parallel incised band with circular punctates & - & 1 \\
\hline parallel incised band with cane punctates & - & 2 \\
\hline vertical incised lines above circular punctates & - & 1 \\
\hline tool punctate-filled incised triangles & 2 & 2 \\
\hline subtotal & 2 & 6 \\
\hline curvilinear appliqued ridges & - & 1 \\
\hline Totals & 26 & 40 \\
\hline
\end{tabular}




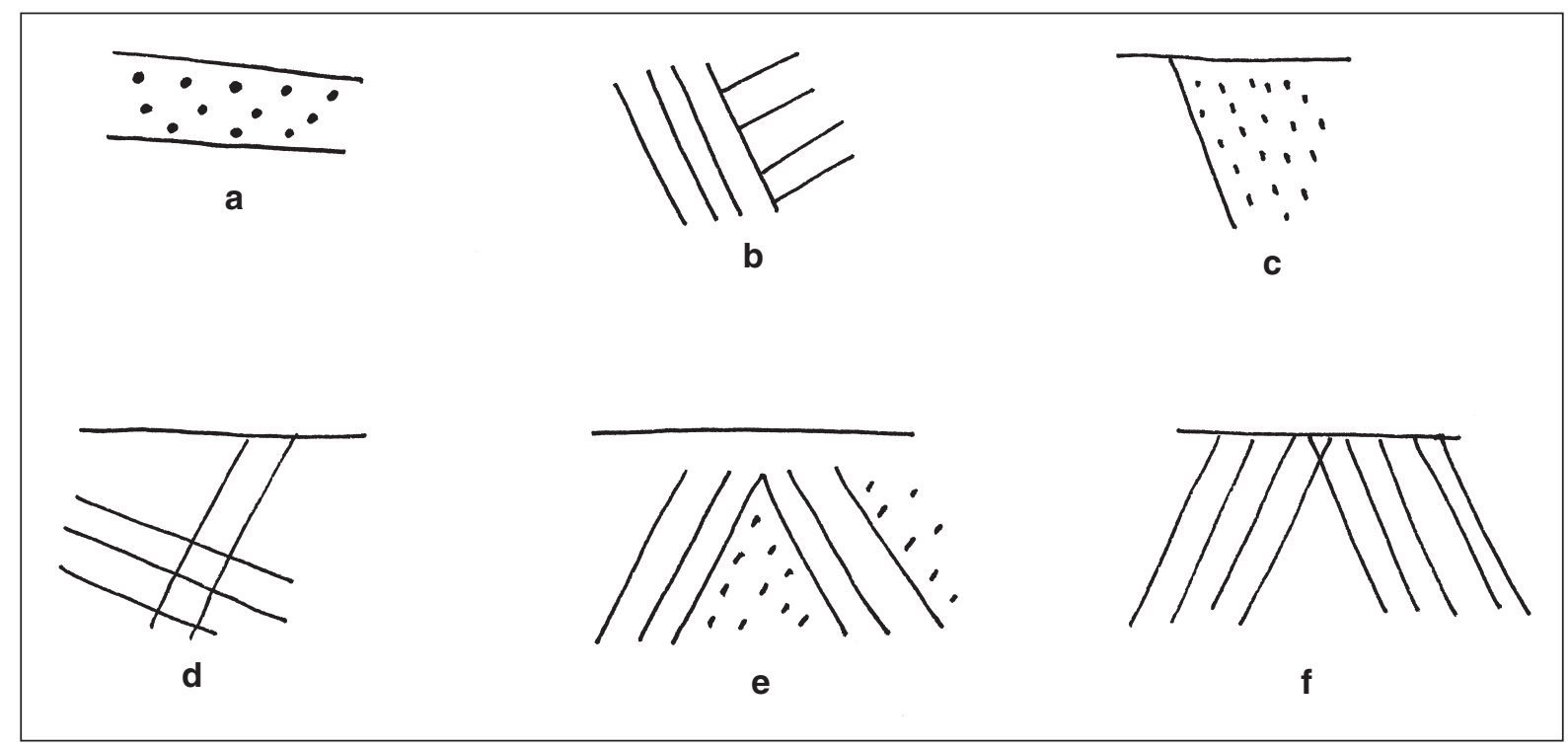

Figure 3. Selected utility ware decorative elements: a, cane punctate-filled incised zone; b, diagonal opposed incised lines; c, tool punctate-filled incised triangle rim; d, cross-hatched incised rim; e, tool punctate-filled and alternating incised triangles; f, opposed incised rim. Provenience: a, N98 E 54 (Lot 127); b, N100 E52, lv. 5 (Lot 122); c, N98 E54 (Lot 123); d, N95 E55, 1v. 6 (Lot 158); e, N99 E54 (Lot 126); f, N99 E58 (Lot 110).

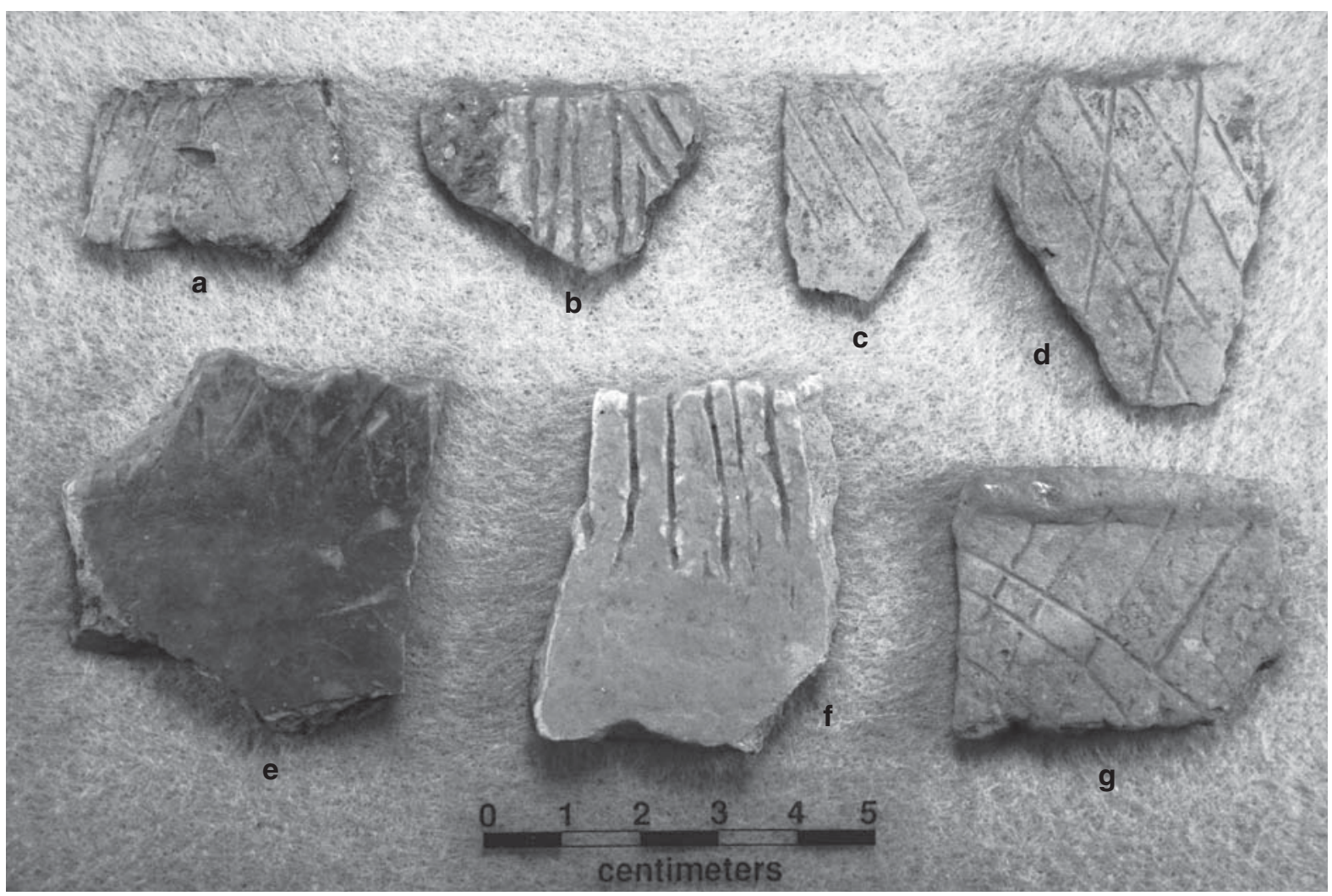

Figure 4. Incised sherds from 41LR351: top row, left to right: a, opposed incised rim (N99 E58, Lot 110); b, opposed incised lines (N98 E54, Lot 123); c, diagonal incised rim (N99 E58, Lot 112); d; cross-hatched incised (N98 E54, Lot 127); bottom row, left to right: e, cross-hatched incised (N98 E54, Lot 127); f, vertical incised lines (N100 E52, Lot 122); g, cross-hatched incised rim (N100 E52, Lot 152). 


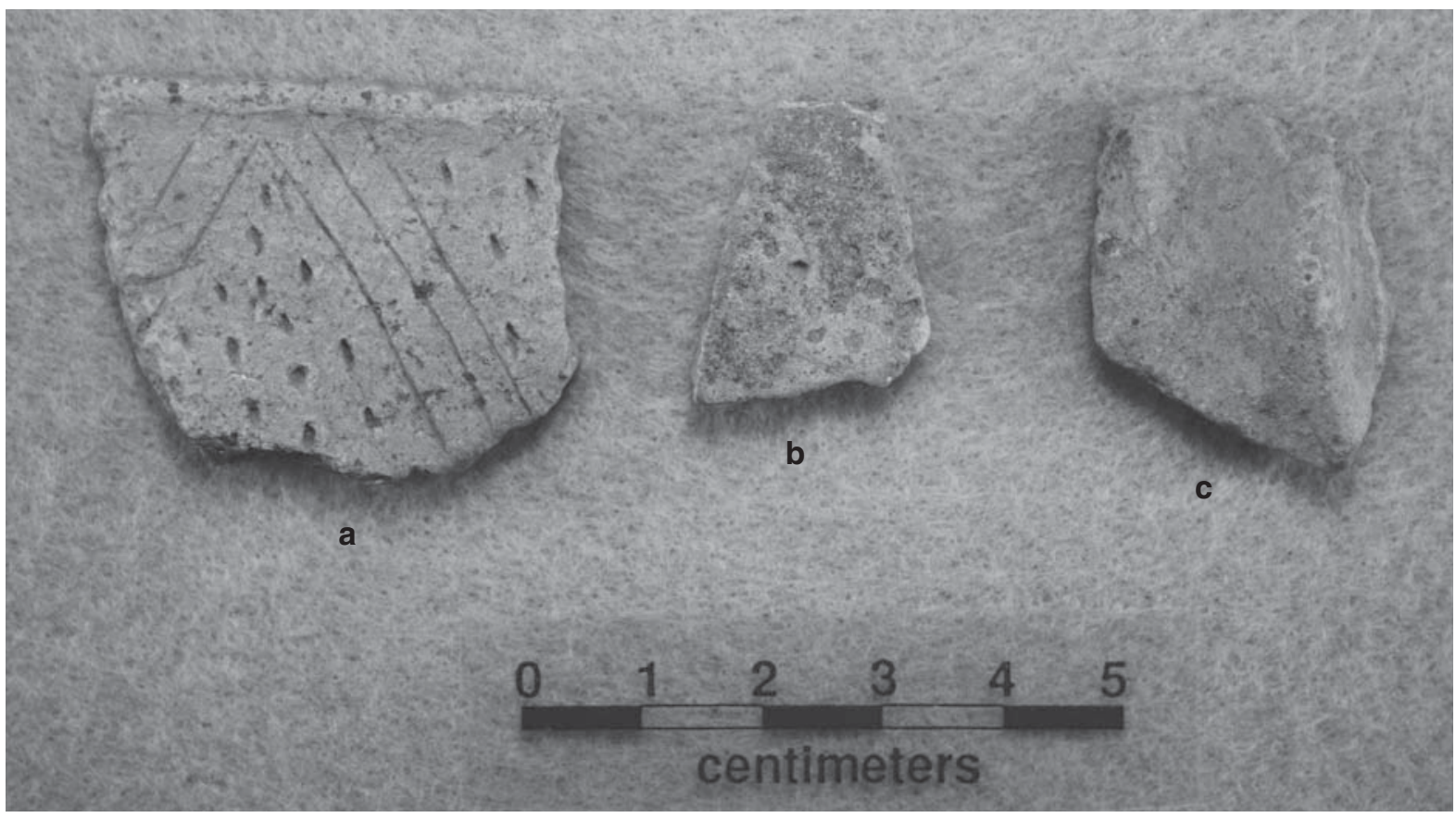

Figure 5. Incised-punctated and appliqued utility ware sherds: left to right: a, Canton Incised rim (N99 E54, Lot 126); b, possible Pennington Punctated-Incised body sherd (N98 E54, Lot 127); c, appliqued body sherd (N98 E54, Lot 130).

41LR351 that may be from Pennington PunctatedIncised vessels (see Figures $3 \mathrm{a}$ and $5 \mathrm{~b}$ ). These have well-defined parallel incised bands filled with either circular or cane punctations (see Table 3 ).

Other utility ware vessel at 41LR351 may have had a punctated zone (or rows of punctations) around the top of the vessel, or perhaps had punctations on both the rim and body. In these cases, the punctations were made with tools, fingernails, or a cut piece of cane (Figure 6a-d; see Table 3). One body sherd has curvilinear appliqued ridges on it (see Figure 5c), perhaps part of a modeled element attached to the vessel surface.

\section{PLAIN SHERDS}

The 481 plain sherds from 41LR351 account for $80.5 \%$ of the ceramic assemblage. The plain sherds include 16 rim sherds ( $30.2 \%$ of all the rims), 432 body sherds ( $84.2 \%$ of all the body sherds), and 33 base sherds.

Based on the proportion of decorated $(n=37)$ and plain rims $(n=16)$, and the assumption that the number of rims is an accurate proxy for the relative frequency of vessels of different kinds, about $30 \%$ of the vessels at 41LR351 are from plain, non-slipped vessels. At the Stallings site, by contrast, $89 \%$ of the rims are from plain, non-slipped vessels (Perttula 2008a).

\section{DISCUSSION OF THE CERAMIC ASSEMBLAGE FROM 41LR351}

There are three distinct ceramic wares in the prehistoric Caddo sherd assemblage from 41LR351: fine ware, utility ware, and plain ware. These three wares are not only different with respect to the kind of surface decorations found on them (see above), but also in terms of the technological analyses to be discussed below, including temper and paste, firing conditions, vessel wall thickness, surface treatment, and rim and lip form.

\section{Temper and Paste}

Between $95.5-100 \%$ of the fine ware, utility ware, and plain ware sherds from 41LR351 had grog (crushed sherds) added to the clay paste (Table 4). Crushed and burned bone and crushed hematite were also added to the paste as temper in all three wares. Bone occur in slightly higher but not statistically significant frequencies in the coarser utility 


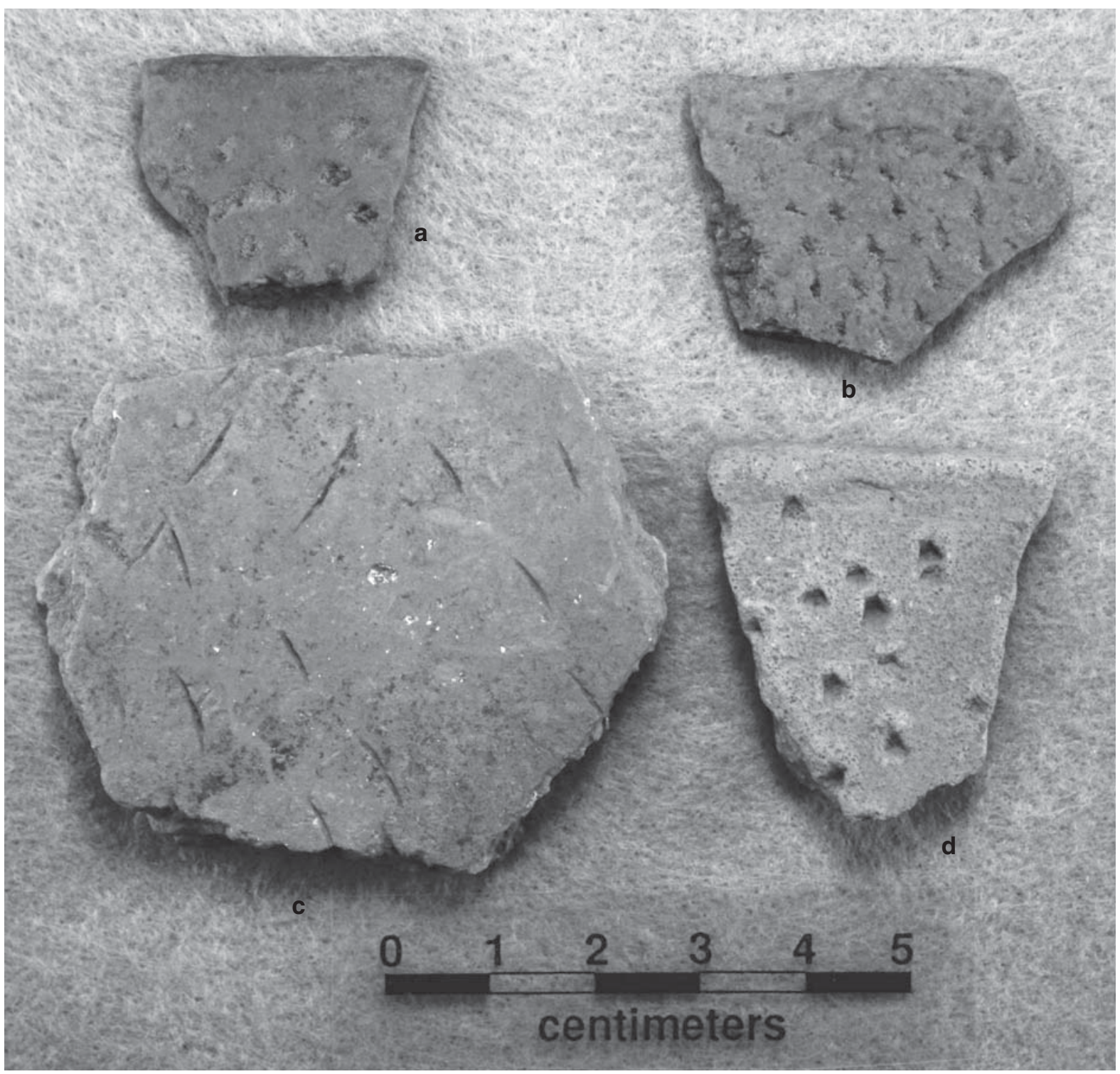

Figure 6. Punctated rim and body sherds from 41LR351: top row, left to right: a, cane punctated rim (N99 E54, Lot 150); b, tool punctated rim (N99 E58, Lot 101); bottom row, left to right: c, fingernail punctated body sherd (N95 E55, Lot 156); d, tool punctated rim (N99 E54, Lot 135).

wares as well as the plain wares, while hematite temper is particularly abundant in the utility wares. Sherds from vessels with a sandy paste (apparently from the infrequent use of a naturally sandy clay) are found in low frequencies $(6.0-6.5 \%)$ in all three wares (Table 4).

The potters that lived at 41LR351 used bone and hematite temper for several reasons. In addition to it likely being a matter of personal preference or part of a family stylistic tradition for particular Caddo potters in vessel manufacture, the addition of coarse fragments of crushed bone and hematite would have made the clay more plastic and increased its strength and use-life, properties that were important in the successful manufacture of durable pottery vessels. Grog, on the other hand, contributes to the ability of the fired vessel to withstand heat-related stresses, as well as increasing its flexural strength. Such vessels would also have had better thermal conductivity (O'Brien et al. 1994:281; Rice 1987:362). These attributes suggest that the grog-tempered wares from 41LR351 were intended for long and common use, both for the cooking of food stuffs but also for serving hot and cold foods. 
Table 4. Temper and paste categories by wares.

\begin{tabular}{|c|c|c|c|}
\hline Temper/paste category & Fine ware & Utility ware & Plain ware \\
\hline Grog & $67.7^{*}$ & 58.3 & $\underline{72.2}$ \\
\hline Grog/sandy paste & 3.2 & 2.1 & 4.5 \\
\hline Grog-organics & $\underline{9.7}$ & 4.2 & 1.5 \\
\hline $\begin{array}{l}\text { Grog-organics/sandy } \\
\text { paste }\end{array}$ & 3.2 & - & - \\
\hline Grog-bone & 9.7 & 12.5 & 11.3 \\
\hline Grog-bone-hematite & 3.2 & 4.2 & 0.8 \\
\hline Grog-hematite & 3.2 & $\underline{10.4}$ & 4.5 \\
\hline $\begin{array}{l}\text { Grog-hematite/sandy } \\
\text { paste }\end{array}$ & - & 4.2 & 0.8 \\
\hline Bone & - & 2.1 & 3.0 \\
\hline Bone-organics & - & 2.1 & 0.8 \\
\hline $\begin{array}{l}\text { Bone-hematite/sandy } \\
\text { paste }\end{array}$ & - & - & 0.8 \\
\hline \multicolumn{4}{|l|}{ Summary: } \\
\hline sherds with grog & 100.0 & 95.8 & 95.5 \\
\hline sherds with bone & 12.9 & $\underline{20.8}$ & 16.5 \\
\hline sherds with hematite & 6.5 & $\underline{18.8}$ & 6.8 \\
\hline sherds with organics & $\underline{12.9}$ & 6.3 & 2.3 \\
\hline sherds with sandy paste & 6.5 & 6.3 & 6.0 \\
\hline Totals & 31 & 48 & 133 \\
\hline
\end{tabular}

*percentage; columns underlined and in bold represent significantly distinct proportions of temper-paste categories

There are differences in the proportion of fine ware and utility ware sherds with either bone (33.3$37.7 \%)$ or hematite $(3.7-4.9 \%)$ temper from the earlier Stallings site ceramic assemblage (Perttula 2008a:Table 4) and the later ceramic assemblage at 41LR351. The use of bone temper seemingly decreased over time-to only $12.9-20.8 \%$ at 41LR351 - while hematite was more frequently selected as a tempering agent (6.5-18.8\%).

\section{Firing Conditions}

The Caddo fine ware and utility vessel sherds, as well as the plain ware sherds, from 41LR351, were fired primarily in a reducing or low oxygen environment, probably smothering the vessel in a bed of coals from a wood fire (Table 5). This method of firing is typical of Caddo ceramic assemblages throughout East Texas, almost without exception. The percentage of fine ware sherds fired in a reducing environment is $90.2 \%$, compared to $73.0 \%$ for the utility wares, and $66.1 \%$ for the plain rims (see below).

After firing, most of the vessels made and used at 41LR351 were apparently cooled in a high oxygen environment (48.3-58.6\%, see Table 5), meaning that the fire-hardened vessels were probably removed from the fire to cool, producing a thin 
Table 5. Firing conditions.

\begin{tabular}{|c|c|c|c|}
\hline Firing category & Fine ware & Utility ware & Plain ware \\
\hline A (Oxidizing) & - & $16.7 *$ & $\underline{18.0}$ \\
\hline B (Reducing) & $\underline{41.9}$ & 16.7 & 7.5 \\
\hline $\mathrm{C}$ & 3.2 & 4.2 & 5.3 \\
\hline D (Incompletely & - & 2.1 & 0.8 \\
\hline E Oxidized) & - & 2.1 & $\underline{5.3}$ \\
\hline $\mathrm{F}$ & 29.0 & 31.3 & 31.6 \\
\hline G (Reducing, cooled & 16.1 & 16.7 & $\underline{22.5}$ \\
\hline $\mathrm{H}$ in open air) & 3.2 & $\underline{8.3}$ & 4.5 \\
\hline K (Sooted, smudged, & - & 2.1 & 2.3 \\
\hline L refired/erratic & 3.2 & - & 0.8 \\
\hline X firing) & 3.2 & - & 1.5 \\
\hline \multicolumn{4}{|l|}{ Summary } \\
\hline Oxidized firing & 0.0 & 16.7 & $\underline{18.0}$ \\
\hline Reduced firing & $\underline{41.9}$ & 16.7 & 7.5 \\
\hline $\begin{array}{l}\text { Incompletely oxidized } \\
\text { firing }\end{array}$ & 3.2 & 8.4 & $\underline{11.4}$ \\
\hline $\begin{array}{l}\text { Reduced firing, open } \\
\text { air cooling }\end{array}$ & 48.3 & 56.3 & $\underline{58.6}$ \\
\hline $\begin{array}{l}\text { Sooted, smudged, } \\
\text { refired/erratic firing }\end{array}$ & $\underline{6.4}$ & 2.1 & 4.6 \\
\hline Totals & 31 & 48 & 133 \\
\hline
\end{tabular}

*percentage; columns underlined and in bold represent significantly distinct proportions of temper-paste categories

oxidized or lighter surface on either one or both vessel surface. The consistency in how the vessels at the site were fired indicates rather clearly that the prehistoric Caddo potters who made those vessels were well-versed in regulating firing and cooling temperatures as well as maintaining control over the final finished end product, namely the manufacture of durable and relatively hard vessels with certain colors and hues.

A few sherds in the three wares (2.1-6.4\%) have distinctive fired cores. These were either fired in an oxidizing environment, then reduced, leaving a thin black band along the vessel interior (firing conditions K and L, Perttula 2005:Figure 5-30k-1). Other sherds - including fine wares and plain wares-have multiple thin bands of reduced and oxidized clay in the vessel core (firing condition $\mathrm{X}$ ).

\section{Thickness of the Ceramic Wares}

The fine ware vessel sherds from 41LR351 are thinner than the decorated utility ware or plain ware sherds, particularly along the body, but the rim walls are also thinner on the fine wares than they are on the decorated utility wares or plain wares (Table 6). For the rims, fine ware vessels are less than $10 \%$ thinnerwalled than either the utility wares or the plain ware vessel rims. Body sherds are about $20 \%$ thinner in the fine wares compared to either the utility or plain wares. 
Table 6. Thickness of the ceramic wares.

\begin{tabular}{llll}
\hline Sherd type & $\begin{array}{l}\text { Fine ware } \\
(\mathrm{mm})\end{array}$ & $\begin{array}{l}\text { Utility ware } \\
(\mathrm{mm})\end{array}$ & $\begin{array}{l}\text { Plain ware } \\
(\mathrm{mm})\end{array}$ \\
\hline Rim & $\begin{array}{l}6.56 \pm 0.47 \\
\text { range, } 5.8-7.9\end{array}$ & $\begin{array}{l}7.00 \pm 1.16 \\
\text { range, } 4.9-10.0\end{array}$ & $\begin{array}{l}6.74 \pm 0.66 \\
\text { range, } 5.9-8.8\end{array}$ \\
Body & $\begin{array}{l}6.16 \pm 0.87 \\
\text { range, } 4.5-8.8\end{array}$ & $\begin{array}{l}7.24 \pm 1.00 \\
\text { range, } 4.2-9.2\end{array}$ & $\begin{array}{l}7.39 \pm 0.82 \\
\text { range, } 4.3-9.6\end{array}$ \\
Base & - & - & $10.79 \pm 0.88$ \\
\hline
\end{tabular}

These variations in vessel wall thickness are likely related to functional and technological differences in how these different wares were intended to be used by Caddo potters. The more substantial vessel walls in the utility wares and plain wares would be well suited to the cooking and heating of foods and liquids and would have contributed to their ability to withstand heat-related stresses. Fine wares were probably intended for use in the serving of foods and liquids.

Another factor that would influence vessel body wall thickness would be the sequence in which a vessel was constructed (Krause 2007:35). Vessels constructed from the bottom up, as these prehistoric Caddo decorated vessels likely were, would tend to have thinner walls moving up the vessel body towards the rim, with the lower portion of the vessel-especially on the base-usually significantly thicker than the upper portions of the vessel.

\section{Surface Treatment}

Fine ware vessel sherds at 41LR351 are more frequently smoothed and/or burnished than the utility wares or plain wares (Table 7), particularly on exterior vessel surfaces. When not burnished, the fine wares tend to be well smoothed on the vessel exterior; it is suspected that most of the fine wares at the site were actually burnished after they were fired, but the burnish has been degraded by time and soil conditions.

Utility ware and plain ware sherds are from vessels that are commonly smoothed on one or both vessel surfaces (see Table 7), with utility ware vessels more likely smoothed on the interior surface, but more frequently smoothed on the exterior surface of plain wares (probably from bowls or the lower and undecorated portion of carinated bowls). The frequency of utility ware vessels that have been

Table 7. Surface treatment by ceramic ware.

\begin{tabular}{|c|c|c|c|}
\hline Surface treatment & Fine ware & Utility ware & Plain ware \\
\hline Interior smoothed & $\underline{48.4} *$ & 27.1 & 15.8 \\
\hline Exterior smoothed & $\underline{48.4}$ & 10.4 & 28.6 \\
\hline Exterior burnished & $\underline{6.5}$ & - & - \\
\hline Interior burnished & - & - & 0.8 \\
\hline Totals & 31 & 48 & 133 \\
\hline
\end{tabular}

*percentage; columns underlined and in bold represent significantly distinct proportions of temper-paste categories 
smoothed on exterior surfaces (10.4\%) suggests that not only were decorations on these vessels most likely restricted to rim or upper vessel areas (and left unsmoothed), but that the undecorated or lower portions of these vessels were sometimes smoothed before or after firing for some purpose.

The smoothing of utility ware interior vessel surfaces $(27.1 \%)$ was probably done to lower the permeability and increase the heating effectiveness of particular vessels in cooking tasks (cf. Rice 1996:148). With the fine wares, the well-smoothed and/or burnished interior surfaces may have been advantageous in the repeated use of these wares as food serving vessels. The purpose of exterior smoothing and burnishing (which are more common surface treatments in the fine wares) may have been for stylistic and display purposes, creating a flat and lustrous surface well-suited to highlight the engraved and/or slipped exterior surfaces of the fine ware vessels.

\section{Rim and Lip Form}

They are several rim and lip forms in the fine ware, utility ware, and plain ware rim sherds (Table 8), suggesting they come from different sorts of vessels of wide-ranging sizes, although the rim sherds are in most cases too small to accurately determine the form of the vessel. Most appear to be from bowls and jars, as well as carinated bowls and bottles. Where measurable, vessel orifice diameters ranged from at least $12.0 \mathrm{~cm}$ to as large as $27.0 \mathrm{~cm}$ in size (see Appendix 1).

Where rim and lip form could be determined, more than $90 \%$ of the rims have a direct or vertical rim profile (see Table 8 ). One rim (2\%) from a fine ware vessel has an everted profile and is probably from a compound bowl with an everted upper rim panel. Most of the vessels in turn have a rounded lip (especially the plain wares), with the remainder having flat lips (especially the utility wares). Several other rims in all three wares have a different and distinct lip treatment, where the lip has been folded over to the exterior surface. This form of lip treatment is present in $45.4 \%$ of the fine ware rims, $12.5 \%$ of the utility ware rims, and $21.4 \%$ of the plain ware rims (see Table 8).

\section{Burned Clay}

There are also seven pieces of burned clay in the ceramic assemblage submitted for analysis from 41LR351 (Table 9). These pieces are likely the fragmentary evidence of the use of clay hearths or earth ovens during the Caddo occupation.

\section{SUMMARY}

Recent excavations by the Valley of the Caddo Archeological Society at 411R351 in the Pine Creek drainage basin in northern Lamar County, Texas, has recovered a substantial $(n=598)$ sherd assemblage from a prehistoric Caddo occupation. These sherds are from hand-made and coiled pottery and include engraved and red-slipped fine wares, incised, punctated, and incised-punctated utility wares, and plain ware vessels. Based on the rim sherds, about $70 \%$ of the vessels made and used at 41LR351 are decorated, and of these, approximately $70 \%$ are utility wares decorated with incised, incised-punctated,

Table 8. Rim and lip form.

\begin{tabular}{lccc}
\hline Rim and Lip Forms & Fine ware & Utility ware & Plain ware \\
\hline Direct-Rounded & $36.3^{*}$ & 41.7 & $\underline{\mathbf{6 4 . 3}}$ \\
Direct-Rounded, ext. folded & $\underline{\mathbf{4 5 . 4}}$ & 12.5 & 14.3 \\
Direct-Flat & 9.1 & $\underline{\mathbf{3 7 . 5}}$ & 7.1 \\
Direct-Flat, ext. folded & - & - & - \\
Everted-Rounded & 9.1 & 8.3 & 7.1 \\
--Rounded & - & 24 & 14 \\
\hline Totals & 11 & & \\
\hline
\end{tabular}

*percentage; columns underlined and in bold represent significantly distinct proportions of temper-paste categories 
Table 9. Burned clay from 41LR351.

\begin{tabular}{lccc}
\hline Lot No. & Provenience & Level & No. of burned clay pieces \\
\hline 110 & N99 E58 & $?$ & 1 \\
130 & N98 E54 & lv. 4 & 2 \\
137 & N98 E54 & lv. 6 & 3 \\
150 & N99 E54 & lv. 5 & 1 \\
\hline
\end{tabular}

and punctated decorative elements. Red-slipped fine wares are also relatively abundant in the fine wares, which is a known feature of Middle Caddo period (ca. A.D. 1100-1300) ceramic assemblages in this part of the Red River basin (Perttula 2008, ed.; Prikryl 2008). Identified or provisionally identified ceramic types in the 41LR351 assemblage are Sanders Engraved, Holly Fine Engraved, Sanders Plain, Canton Incised, and Pennington Punctated-Incised.

The sherds from 41LR351 are from vessels that are tempered primarily with grog (crushed pieces of fired clay), but burned bone, and/or crushed pieces of hematite or a hematitic sandstone are also important tempering agents. Vessel forms represented in the collection are carinated bowls, compound bowls, simple open bowls, bottles, and jars. The vessels have typically been fired in a reducing or low oxygen environment and then cooled in the open air. Vessels are smoothed, but only rarely burnished, on one or both vessel surfaces. These vessels have thick, flat, bases more than $10 \mathrm{~mm}$ in thickness, but mean vessel rim and body walls for all three wares range between 6.16-7.39 $\mathrm{mm}$; no obvious thick Williams Plain (see Brown 1996; Schambach 1998) vessel sherds have been identified in the 41LR351 plain wares.

The ceramic assemblage at 41LR351 shares many characteristics with other prehistoric Caddo ceramic assemblages of Middle Caddo period age in the middle reaches of the Red River basin (i.e., that portion of the Red River just below, and then above, the confluence with the Kiamichi River, but within forested areas of Northeast Texas), the lower reaches of the Kiamichi River basin in southeastern Oklahoma, and the upper South Sulphur River basin. These ceramic assemblages, including 41LR351, appear to date from ca. A.D. 1100 to ca. A.D. 1300, although none of the sites are well-dated through the use of radiocarbon, and also they predate the use of shell-tempered pottery in these areas, as that technological feature does not become a predominant part of local ceramic assemblages until the $14^{\text {th }}$ century (see Early et al. n.d.). In the past, these sites have been included in the now outdated Sanders focus or phase (see Krieger 1946), but currently there is no accepted cultural taxonomic unit for sites of this age and cultural affiliation in this part of Northeast Texas or southeastern Oklahoma.

These sites have grog-tempered assemblages with engraved and red-slipped fine wares (including Sanders Engraved, Sanders Plain, Maxey Noded Redware, and Holly Fine Engraved), a variety of decorated utility wares (among them Canton Incised, Crockett Curvilinear Incised, Pennington Punctated-Incised, and punctated vessels such as Monkstown Fingernail Impressed), and plain slipped and non-slipped wares (not notably thickwalled) are relatively common. The relevant sites on the Red River include Holdeman (41RR11) (Perttula 2008b), Sam Kaufman/Roitsch (41RR16) (Skinner et al. 1969; Perttula 2008, ed.), Fasken (41RR14) (Prikryl 2008), and Sanders (41LR2) (Krieger 1946, 2000) in Texas, and the Nelson (34Ch6) and Cook (34Ch7) sites in southeastern Oklahoma (Rohrbaugh 1973:184-193; Wyckoff and Fisher 1985:Figures 2 and 30); the Pat Boyd (34Ch113), Hugo Dam (34Ch112), and Mahaffey (34Ch1) sites on the lower Kiamichi River (Burton 1970; Rohrbaugh 1973; Perino and Bennett 1978; the Snapping Turtle (41LR11), Weekend Warrior (41LR31), and Cundleff (41LR29) sites on Sanders Creek (Lorrain and Hoffrichter 1968); A. C. Mackin (41RR36) and Neely (41RR61) on Big Pine Creek (Mallouf 1976); and Hurricane Hill (41HP106) in the upper reaches of the South Sulphur River (Perttula 1999).

Examining in more detail the characteristics of ceramic assemblages in Red River and Lamar counties, Texas, including 41LR351, it is possible to recognize temporal differences between them (Table 10). The earlier components include the Ray site (Bruseth et al. 2001) and 41LR297 (Perttula 2008a). These are plain ware-dominated and grog 
Table 10. Comparisons with selected nearby prehistoric Caddo ceramic assemblages in Northeast Texas.

\begin{tabular}{|c|c|c|c|c|}
\hline \multirow[t]{2}{*}{ Assemblage Attributes } & \multicolumn{4}{|c|}{ Sites } \\
\hline & Ray & $\begin{array}{l}\text { Sam } \\
\text { Kaufman* }\end{array}$ & 41LR297 & 41LR351 \\
\hline Decorated sherds & 101 & 163 & 88 & 117 \\
\hline Plain sherds & 5719 & 792 & 1255 & 481 \\
\hline P/DR & $56.6: 1$ & $4.86: 1$ & $14.3: 1$ & $4.11: 1$ \\
\hline Grog temper $\%$ & 73 & 94 & $90 * *$ & $96 * *$ \\
\hline Bone temper $\%$ & 27 & 6 & $32 * *$ & $17 * *$ \\
\hline Incised sherds & 83 & 63 & 40 & 45 \\
\hline Punctated sherds & 14 & 19 & 13 & 12 \\
\hline Incised-punctated sherds & - & 2 & 8 & 8 \\
\hline Appliqued sherds & - & - & - & 1 \\
\hline Brushed sherds & 3 & - & - & - \\
\hline Engraved sherds & 1 & 1 & 27 & 33 \\
\hline Red-slipped & - & 70 & - & 18 \\
\hline Coles Creek Incised & + & + & + & \\
\hline Crockett Curvilinear Incised & + & + & + & \\
\hline French Fork Incised & + & + & & \\
\hline Hickory/Holly Engraved & & & + & + \\
\hline Williams Plain & + & + & & \\
\hline
\end{tabular}

*East Mound (Skinner et al. 1969: Tables 5 and 6)

**percentages do not total to $100 \%$ because many sherds have more than one tempering agent $+=$ present

and bone-tempered ceramic assemblages. At the Ray site, which has nine calibrated radiocarbon dates that range from AD 700-1200 (Bruseth et al. 2001:Table 11) — with six that postdate AD 1000 the P/DR value is 56.6:1. Site 41LR297 has no radiocarbon dates, but the Caddo occupation there appears to pre-date ca. A.D. 1150 . With respect to the different kinds of decorated sherds found in these Early Caddo assemblages, incised decorative elements predominate. These incised vessels have primarily simple straight line and geometric designs, with a number of horizontally incised rims, including rims from Coles Creek Incised vessels along with Caddo types such as Davis Incised, Dunkin Incised, and Kiam Incised. Incised and incised- punctated elements from Crockett Curvilinear Incised vessels are also important constituents of these Early Caddo ceramic assemblages, and Coles Creek Incised vessel sherds are present at both Ray and 41LR297. Engraved sherds from Hickory and Holly Fine Engraved vessels comprise 30\% of the decorated sherds at 41LR297. Red-slipped sherds are not present.

Later, ca. A.D. 1100-1300, Caddo ceramic assemblages are present in the East Mound at the Sam Kaufman site and 41LR351. Excavations at the East Mound at Sam Kaufman recovered a ceramic assemblage from archeological deposits (House 3) with four calibrated dates: their mean age ranges from AD 1008-1206 (Perttula 1998:334). The P/DR 
of this assemblage is 4.86:1 (see Table 10), roughly comparable to the P/DR from 41LR351, and both have considerably lower P/DR values than do the pre-A.D. 1100/1150 assemblages at the Ray site and 41LR297 (14.3:1 to 56.6:1). These post-ca. A.D. 1100 Caddo ceramic assemblages apparently have at least three times the percentage of decorated vessels and vessel sherds when compared to their pre-A.D. 1100 counterparts in the same region. Red-slipped sherds are also common in both post-A.D. 1100 assemblages (see Table 10). Finally, the use of bone temper by Caddo potters appears to have decreased from pre-A.D. 1100 (27-32\%) to post-A.D. 1100 $(6-17 \%)$ contexts.

\section{ACKNOWLEDGMENTS}

I would like to thank the Valley of the Caddo Archaeological Society, especially Gary Sykes, for the opportunity to study the ceramic sherds from 41LR351. Bo Nelson took the digital photographs of selected sherds to accompany this article.

\section{REFERENCES CITED}

Brown, J. A.

1996 The Spiro Ceremonial Center: The Archaeology of Arkansas Valley Caddoan Culture in Eastern Oklahoma. 2 Vols. Memoirs No. 29. Museum of Anthropology, University of Michigan, Ann Arbor.

Bruseth, J. E. and T. K. Perttula, with contributions by G. J.

Fritz and B. C. Yates

2006 Archeological Investigations at the Hudnall-Pirtle Site (41RK4): An Early Caddo Mound Center in Northeast Texas. Caddo Archeology Journal 15:57-158.

Bruseth, J. E., L. Banks, and J. Smith

2001 The Ray Site (41LR135). Bulletin of the Texas Archeological Society 72:197-213.

Bruseth, J., J. Durst, R. Proctor, L. Banks, G. Sykes, and B. Pierson

2009 Investigations at the Gene and Ruth Ann Stallings Ranch Site (41LR297). Bulletin of the Texas Archeological Society 80:195-205.

Burton, S. S.

1970 The Hugo Dam Site, Ch-112, Choctaw County, Southeast Oklahoma. Archaeological Site Report No. 16. Oklahoma River Basin Survey, University of Oklahoma Research Institute, Norman.
Early, A. M., J. S. Girard, T. K. Perttula, and M. B. Trubitt

n.d. The Use of Shell-Tempered Pottery in the Caddo Area and the Far Southeast. MS on file with the authors.

Krause, R. A.

2007 A Potter's Tale. In Plains Village Archaeology: Bison-hunting Farmers in the Central and Northern Plains, edited by S. A. Ahler and M. Kay, pp. 32-40. University of Utah Press, Salt Lake City.

Krieger, A. D.

1946 Culture Complexes and Chronology in Northern Texas With Extensions of Puebloan Datings to the Mississippi Valley. Publication No. 4640. The University of Texas at Austin.

2000 The Pottery of the Sanders Farm. In The 1931 Excavations at the Sanders Site, Lamar County, Texas: Notes on the Fieldwork, Human Osteology, and Ceramics, by A. T. Jackson, M. S. Goldstein, and A. D. Krieger, pp. 131-144. Archival Series 2. Texas Archeological Research Laboratory, The University of Texas at Austin,

Lorrain, D. and N. Hoffrichter

1968 Archeological Survey and Excavation at Pat Mayse Reservoir, Texas. Report submitted to the National Park Service by Southern Methodist University, Dallas.

Mallouf, R. J.

1976 Archeological Investigations at Proposed Big Pine Lake, 1974, 1975, Lamar and Red River Counties, Texas. Archeological Survey Report 18. Texas Historical Commission, Austin.

O'Brien, M. J., T. D. Holland, R. J. Hoard, and G. L. Fox

1994 Evolutionary Implications of Design and Performance Characteristics of Prehistoric Pottery. Journal of Archaeological Method and Theory 1:259-304.

Perino, G. and W. J. Bennett, Jr.

1978 Archaeological Investigations at the Mahaffey Site, Ch-1, Hugo Reservoir, Choctaw County, Oklahoma. Museum of the Red River, Idabel, Oklahoma.

Perttula, T. K.

1998 A Compendium of Radiocarbon and Oxidizable Carbon Ratio Dates from Archaeological Sites in East Texas, with a Discussion of the Age and Dating of Select Components and Phases. Radiocarbon 39(3):305-341.

2004 The Prehistoric and Caddoan Archeology of the Northeastern Texas Pineywoods. In The Prehistory of Texas, edited by T. K. Perttula, pp. 370-407. Texas A\&M University Press, College Station. 
2008a The Decorated Ceramic Sherds, Plain Rims, and Clay Pipe Sherds from the Stallings Site (41LR297), Lamar County, Texas. MS on file with the author.

2008b Archeological Survey of the Roitsch Farm and Adjoining Lands, 1991 and 1992 Texas Archeological Society Field School, Red River County, Texas. In Collected Papers from Past Texas Archeological Society Summer Field Schools, edited by T. K. Perttula, pp. 173-312. Special Publication No. 5. Texas Archeological Society, San Antonio.

Perttula, T. K. (editor)

1999 The Hurricane Hill Site (41HP106): The Archaeology of a Late Archaic/Early Ceramic and EarlyMiddle Caddoan Settlement in Northeast Texas. 2 Vols. Special Publication No. 4. Friends of Northeast Texas Archaeology, Pittsburg and Austin.

2005 Archeological Investigations at the Pilgrim's Pride Site (41CP304), a Titus Phase Community in the Big Cypress Creek Basin, Camp County, Texas. 2 Vols. Report of Investigations No. 30. Archeological \& Environmental Consultants, LLC, Austin.

2008 The Archeology of the Roitsch Site (41RR16), an Early to Historic Caddo Period Village on the Red River in Northeast Texas. In Collected Papers from Past Texas Archeological Society Summer Field Schools, edited by T. K. Perttula, pp. 313-628. Special Publication No. 5. Texas Archeological Society, San Antonio.

Perttula, T. K., M. R. Miller, R. A. Ricklis, D. J. Prikryl, and C. Lintz

1995 Prehistoric and Historic Aboriginal Ceramics in Texas. Bulletin of the Texas Archeological Society 66:175-235.

Prikryl, D. J.

2008 The 1991 and 1992 Texas Archeological Society Field School Excavations at the Fasken Site (41RR14), Red River County, Texas. In Collected Papers from Past Texas Archeological Society Summer Field Schools, edited by T. K. Perttula, pp. 125171. Special Publication No. 5. Texas Archeological Society, San Antonio.

Rice, P. M.

1987 Pottery Analysis: A Sourcebook. University of Chicago Press, Chicago.

1996 Recent Ceramic Analysis: 1. Function, Style, and Origins. Journal of Archaeological Research 4(2):133-163.
Rohrbaugh, C. L.

1973 Hugo Reservoir III: A Report on the Early Formative Cultural Manifestations in Hugo Reservoir and in the Caddoan Area. Archaeological Site Report No. 24. Oklahoma River Basin Survey, University of Oklahoma Research Institute, Norman, Oklahoma.

Schambach, F. F.

1998 Pre-Caddoan Cultures in the Trans-Mississippi South: A Beginning Sequence. Research Series 53. Arkansas Archeological Survey, Fayetteville.

Schambach, F. F. and J. E. Miller

1984 A Description and Analysis of the Ceramics. In Cedar Grove: An Interdisciplinary Investigation of a Late Caddo Farmstead in the Red River Valley, edited by N. L. Trubowitz, pp. 109-170. Research Series No. 23. Arkansas Archeological Survey, Fayetteville.

Skinner, S. A., R. K. Harris, and K. M. Anderson (editors)

1969 Archaeological Investigations at the Sam Kaufman Site, Red River County, Texas. Contributions in Anthropology No. 5. Southern Methodist University, Dallas.

Story, D. A.

2000 Introduction. In The George C. Davis Site, Cherokee County, Texas, by H. P. Newell and A. D. Krieger, pp. 1-31. $2^{\text {nd }}$ Edition. Society for American Archaeology, Washington, D.C.

Suhm, D. A. and E. B. Jelks (editors)

1962 Handbook of Texas Archeology: Type Descriptions. Special Publication No. 1, Texas Archeological Society, and Bulletin No. 4, Texas Memorial Museum, Austin.

Teltser, P. A.

1993 An Analytic Strategy for Studying Assemblage-Scale Ceramic Variation: A Case Study from Southeast Missouri. American Antiquity 58(3):530-543.

Wyckoff, D. G. and L. R. Fisher

1985 Preliminary Testing and Evaluation of the Grobin Davis Archeological Site, 34Mc-253, McCurtain County, Oklahoma. Archeological Resource Survey Report No. 22. Oklahoma Archeological Survey, Norman. 
Appendix 1, Detailed Analysis of Decorated and Plain Sherds from 41LR351.

\begin{tabular}{|c|c|c|c|c|c|c|}
\hline $\begin{array}{l}\text { Lot/Provenience } \\
(\mathrm{N}-\mathrm{E})\end{array}$ & Sherd type & Temper & FC & ST & $\begin{array}{l}\text { Th } \\
(\mathrm{mm})\end{array}$ & Decoration \\
\hline \multirow[t]{2}{*}{$100 / 100-52$} & $\operatorname{rim}(\mathrm{EV}-\mathrm{Ro})$ & $\mathrm{g}$ & $\mathrm{B}$ & $\mathrm{I} / \mathrm{E} \mathrm{SM}$ & 5.8 & $\begin{array}{l}\text { horizontal and diagonal } \\
\text { engraved lines; int./ext. } \\
\text { red-slipped }\end{array}$ \\
\hline & base & $\mathrm{g}$ & $\mathrm{F}$ & E SM & 10.8 & plain \\
\hline \multirow[t]{2}{*}{$101 / 99-58$} & $\begin{array}{l}\operatorname{rim}(\mathrm{D}-\mathrm{RO} \\
+12 \mathrm{~cm} \text { OD) }\end{array}$ & g & $\mathrm{B}$ & - & 5.6 & $6+$ tool punctated rows \\
\hline & body & $\mathrm{g}$ & G & - & 9.0 & plain \\
\hline \multirow[t]{2}{*}{ 103/100-51 } & body & g-o & $\mathrm{H}$ & I SM & 7.9 & parallel incised lines \\
\hline & body & $g-b$ & $\mathrm{~F}$ & - & 4.8 & plain \\
\hline \multirow[t]{2}{*}{$106 / 99-58$} & $\operatorname{rim}(\mathrm{D}-\mathrm{FL})$ & $\mathrm{g}$ & A & - & 7.3 & $\begin{array}{l}\text { vertical and diagonal } \\
\text { incised lines }\end{array}$ \\
\hline & body & $\mathrm{g}$ & A & E SM & 7.4 & plain \\
\hline \multirow[t]{2}{*}{ 107/99-58, lv. 3} & body & $\mathrm{g}$ & $\mathrm{G}$ & E SM & 7.9 & plain \\
\hline & base & $\mathrm{g}$ & $\mathrm{G}$ & - & 10.2 & plain \\
\hline \multirow[t]{3}{*}{$108 / 100-52$} & body & $\mathrm{g}$ & $\mathrm{C}$ & - & - & parallel engraved lines \\
\hline & body & $\mathrm{g}$ & $\mathrm{F}$ & - & 8.2 & plain \\
\hline & $\operatorname{rim}(\mathrm{D}-\mathrm{Ro})$ & $\mathrm{g}$ & $\mathrm{G}$ & - & 6.7 & plain \\
\hline $109 / 100-51$ & body & g & $\mathrm{A}$ & E SM & 8.3 & plain \\
\hline \multirow[t]{4}{*}{ 110/99-58 } & $\begin{array}{l}\operatorname{rim}(D-F L \\
\text { ext f) }\end{array}$ & $\mathrm{g}$ & $\mathrm{B}$ & - & 6.4 & $\begin{array}{l}\text { diagonal opposed incised } \\
\text { lines }\end{array}$ \\
\hline & body & $\mathrm{g}$ & $\mathrm{F}$ & - & 7.6 & plain \\
\hline & body & $\mathrm{g}$ & $\mathrm{A}$ & E SM & 7.7 & plain \\
\hline & body & $\mathrm{g}$ & A & - & 6.5 & plain \\
\hline \multirow[t]{2}{*}{$111 / 99-58$} & body & $b-g$ & $\mathrm{C}$ & E SM & 4.3 & plain \\
\hline & body & g & G & E SM & 8.0 & plain \\
\hline \multirow[t]{4}{*}{$112 / 99-58$} & $\operatorname{rim}(\mathrm{D}-\mathrm{FL})$ & $\mathrm{g}$ & $\mathrm{A}$ & E SM & 5.4 & diagonal incised lines \\
\hline & body & g & $\mathrm{G}$ & $\mathrm{I} / \mathrm{E} \mathrm{SM}$ & 5.6 & plain \\
\hline & body & g & $\mathrm{B}$ & I SM & 7.9 & plain \\
\hline & body & $\mathrm{g}$ & G & I SM & 7.3 & plain \\
\hline \multirow[t]{5}{*}{$113 / 99-58$} & body & $\mathrm{g}$ & $\mathrm{F}$ & - & 7.7 & $\begin{array}{l}\text { broad parallel incised } \\
\text { lines }\end{array}$ \\
\hline & body, Jar & $\mathrm{g}$ & $\mathrm{G}$ & I SM & 6.9 & $2+$ tool punctated rows \\
\hline & base & $g-b$ & A & - & 12.2 & plain \\
\hline & body & $\mathrm{b}$ & $\mathrm{F}$ & $\mathrm{I} / \mathrm{E} \mathrm{SM}$ & 6.6 & plain \\
\hline & body & $\mathrm{g} / \mathrm{SP}$ & $\mathrm{F}$ & E SM & 8.2 & plain \\
\hline
\end{tabular}


Appendix 1, Detailed Analysis of Decorated and Plain Sherds from 41LR351, cont'd.

\begin{tabular}{|c|c|c|c|c|c|c|}
\hline $\begin{array}{l}\text { Lot/Provenience } \\
(\mathrm{N}-\mathrm{E})\end{array}$ & Sherd type & Temper & $\mathrm{FC}$ & ST & $\begin{array}{l}\text { Th } \\
(\mathrm{mm})\end{array}$ & Decoration \\
\hline \multirow[t]{4}{*}{$114 / 100-52$} & body & $\mathrm{g}$ & $\mathrm{B}$ & - & 8.3 & plain \\
\hline & body & $\mathrm{g}$ & G & I SM & 6.0 & plain \\
\hline & body, CB & $g-b$ & $\mathrm{G}$ & E SM & 6.3 & plain \\
\hline & body & $\mathrm{g}$ & $\mathrm{B}$ & - & 7.5 & plain \\
\hline \multirow[t]{2}{*}{ 115/101-53, lv. 2} & body & $\mathrm{g}-\mathrm{h} / \mathrm{SP}$ & $\mathrm{X}$ & - & 8.0 & plain \\
\hline & body & $\mathrm{g}$ & $\mathrm{A}$ & E SM & 7.7 & plain \\
\hline \multirow[t]{7}{*}{ 116/101-53, 1v. 3} & $\operatorname{rim}(-\mathrm{Ro})$ & $g-b$ & $\mathrm{~F}$ & - & 6.6 & diagonal incised lines \\
\hline & body & $\mathrm{g}$ & G & - & 6.0 & $\begin{array}{l}\text { cross-hatched incised } \\
\text { lines }\end{array}$ \\
\hline & body, CB & b-g & $\mathrm{X}$ & - & 6.0 & $\begin{array}{l}\text { int. horizontal engraved } \\
\text { lines }\end{array}$ \\
\hline & $\begin{array}{l}\operatorname{rim}(D-F L \\
\operatorname{ext} f)\end{array}$ & $\mathrm{g}$ & $\mathrm{B}$ & E SM & 6.2 & plain \\
\hline & base & g & $\mathrm{G}$ & - & 9.5 & plain \\
\hline & body & $\mathrm{g}$ & $\mathrm{F}$ & - & 8.3 & plain \\
\hline & body & g-h & $\mathrm{A}$ & $\mathrm{I} / \mathrm{E} \mathrm{SM}$ & 5.9 & plain \\
\hline \multirow[t]{3}{*}{$117 / 101-53$} & body & $\mathrm{g}$ & $\mathrm{F}$ & - & 5.7 & $\begin{array}{l}\text { diagonal engraved lines; } \\
\text { red-slipped }\end{array}$ \\
\hline & $\operatorname{rim}(\mathrm{D}-\mathrm{FL})$ & $\mathrm{g}$ & $\mathrm{H}$ & - & 8.9 & $\begin{array}{l}\text { cross-hatched incised } \\
\text { lines }\end{array}$ \\
\hline & body & $\mathrm{g}$ & $\mathrm{L}$ & E SM & 7.7 & plain \\
\hline \multirow[t]{3}{*}{$118 / 99-54$} & base & $g-b$ & A & - & 11.8 & plain \\
\hline & body & g & G & E SM & 7.2 & plain \\
\hline & body & g-b & $\mathrm{F}$ & - & 8.4 & plain \\
\hline \multirow[t]{2}{*}{$119 / 97-60$} & $\operatorname{rim}(\mathrm{D}-\mathrm{Ro})$ & g & $\mathrm{F}$ & E SM & 6.9 & plain \\
\hline & body & $\mathrm{g}$ & $\mathrm{F}$ & - & 7.2 & plain \\
\hline \multirow[t]{5}{*}{$120 / 100-51$} & body & $\mathrm{g}-\mathrm{o} / \mathrm{SP}$ & G & I SM & 6.9 & ext. red-slipped \\
\hline & body & g-o & $\mathrm{F}$ & I SM & 8.8 & $\begin{array}{l}\text { cross-hatched incised } \\
\text { lines }\end{array}$ \\
\hline & body & g-h & $\mathrm{F}$ & I/E SM & 8.4 & $\begin{array}{l}\text { cross-hatched incised } \\
\text { lines }\end{array}$ \\
\hline & body & g-h & $\mathrm{F}$ & - & 8.0 & plain \\
\hline & body & $\mathrm{g}$ & $\mathrm{B}$ & - & 5.5 & plain \\
\hline \multirow[t]{3}{*}{$121 / 98-54$} & body & g-b & $\mathrm{G}$ & - & 5.5 & plain \\
\hline & body & $\mathrm{g}$ & $\mathrm{H}$ & - & 8.1 & plain \\
\hline & body & g-h & $\mathrm{F}$ & - & 8.1 & plain \\
\hline
\end{tabular}


Appendix 1, Detailed Analysis of Decorated and Plain Sherds from 41LR351, cont'd.

\begin{tabular}{|c|c|c|c|c|c|c|}
\hline $\begin{array}{l}\text { Lot/Provenience } \\
(\mathrm{N}-\mathrm{E})\end{array}$ & Sherd type & Temper & $\mathrm{FC}$ & ST & $\begin{array}{l}\text { Th } \\
(\mathrm{mm})\end{array}$ & Decoration \\
\hline \multirow[t]{5}{*}{ 122/100-52, lv. 5} & body & g-h & A & I SM & 9.0 & vertical incised lines \\
\hline & body & $\mathrm{g}-\mathrm{h} / \mathrm{SP}$ & A & - & 5.6 & $\begin{array}{l}\text { opposed diagonal incised } \\
\text { lines }\end{array}$ \\
\hline & body & $\mathrm{g}$ & $\mathrm{F}$ & $\mathrm{I} / \mathrm{E} \mathrm{SM}$ & 7.6 & $\begin{array}{l}\text { parallel engraved lines; } \\
\text { red pigment }\end{array}$ \\
\hline & body & $\mathrm{g}$ & A & - & 6.5 & plain \\
\hline & body & g & $\mathrm{B}$ & - & 9.0 & plain \\
\hline \multirow[t]{11}{*}{$123 / 98-54$} & body & $\mathrm{g}$ & $\mathrm{F}$ & - & 7.9 & opposed incised lines \\
\hline & body & g & $\mathrm{G}$ & - & 8.2 & parallel incised lines \\
\hline & body & $\mathrm{g}$ & $\mathrm{B}$ & - & 6.5 & vertical incised lines \\
\hline & body & g-b-h & $\mathrm{L}$ & - & 5.9 & diagonal engraved lines \\
\hline & $\operatorname{rim}(\mathrm{D}-\mathrm{Ro})$ & $\mathrm{g}-\mathrm{h}$ & A & - & 4.9 & $\begin{array}{l}\text { tool punctate-filled incised } \\
\text { triangle }\end{array}$ \\
\hline & rim & $\mathrm{g} / \mathrm{SP}$ & A & I SM & 10.0 & $\begin{array}{l}\text { large circular punctated } \\
\text { rows }\end{array}$ \\
\hline & base & $\mathrm{g}$ & $\mathrm{F}$ & - & 10.5 & plain \\
\hline & body & g & $\mathrm{K}$ & - & 8.8 & plain \\
\hline & body & $\mathrm{g}$ & $\mathrm{F}$ & - & 7.2 & plain \\
\hline & body & $\mathrm{g}$ & $\mathrm{A}$ & - & 7.0 & plain \\
\hline & body & $\mathrm{g}$ & $\mathrm{B}$ & E SM & 6.8 & plain \\
\hline \multirow[t]{5}{*}{$124 / 98-54$} & body & $\mathrm{g}$ & $\mathrm{E}$ & - & 8.4 & plain \\
\hline & body & g-o & $\mathrm{F}$ & - & 8.5 & plain \\
\hline & body & b-g & $\mathrm{H}$ & I SM & 8.7 & plain \\
\hline & body & g & $\mathrm{F}$ & - & 7.6 & plain \\
\hline & body & $\mathrm{g}$ & $\mathrm{F}$ & - & 7.2 & plain \\
\hline \multirow[t]{6}{*}{$125 / 99-54$} & body & $\mathrm{g} / \mathrm{SP}$ & $\mathrm{F}$ & - & 7.2 & diagonal engraved lines \\
\hline & body & g & $\mathrm{F}$ & I SM & 5.9 & parallel engraved lines \\
\hline & body, Bottle & $g-b$ & B & - & 4.5 & ext. red-slipped \\
\hline & body & $\mathrm{g} / \mathrm{SP}$ & $\mathrm{F}$ & - & 7.1 & plain \\
\hline & body & $\mathrm{b}-\mathrm{o}$ & G & E SM & 9.2 & plain \\
\hline & body & $\mathrm{g}$ & G & - & 7.4 & plain \\
\hline \multirow[t]{7}{*}{$126 / 99-54$} & body & g-h & B & I/E SM & 6.4 & int./ext. red-slipped \\
\hline & body & $\mathrm{g}$ & $\mathrm{B}$ & I/E SM & 7.0 & int./ext. red-slipped \\
\hline & body & $\mathrm{g}-\mathrm{b}$ & $\mathrm{D}$ & - & 7.1 & $2+$ tool punctated rows \\
\hline & $\begin{array}{l}\operatorname{rim}(\mathrm{D}-\mathrm{Ro}, \\
\operatorname{ext} \mathrm{f})\end{array}$ & $\mathrm{g}-\mathrm{h} / \mathrm{SP}$ & $\mathrm{F}$ & - & 7.3 & $\begin{array}{l}\text { cross-hatched incised } \\
\text { lines }\end{array}$ \\
\hline & $\operatorname{rim}(\mathrm{D}-\mathrm{FL})$ & b-o & $\mathrm{F}$ & - & 5.4 & $\begin{array}{l}\text { tool punctate-filled } \\
\text { and alternating incised } \\
\text { triangles }\end{array}$ \\
\hline & body & g & $\mathrm{H}$ & - & 8.0 & diagonal incised lines \\
\hline & body, Jar & $\mathrm{g}$ & G & - & 7.6 & $2+$ linear punctated rows \\
\hline
\end{tabular}


Appendix 1, Detailed Analysis of Decorated and Plain Sherds from 41LR351, cont'd.

\begin{tabular}{|c|c|c|c|c|c|c|}
\hline $\begin{array}{l}\text { Lot/Provenience } \\
(\mathrm{N}-\mathrm{E})\end{array}$ & Sherd type & Temper & $\mathrm{FC}$ & $\mathrm{ST}$ & $\begin{array}{l}\text { Th } \\
(\mathrm{mm})\end{array}$ & Decoration \\
\hline \multirow[t]{6}{*}{ 126/99-54, cont'd. } & $\operatorname{rim}(\mathrm{D}-\mathrm{Ro})$ & $\mathrm{g}$ & $\mathrm{H}$ & - & 6.0 & plain \\
\hline & body & $\mathrm{g}$ & $\mathrm{C}$ & - & 8.6 & plain \\
\hline & body & $\mathrm{g}$ & $\mathrm{C}$ & - & 8.4 & plain \\
\hline & body & $\mathrm{g}$ & $\mathrm{F}$ & - & 6.7 & plain \\
\hline & body & $g-b$ & G & I SM & 6.7 & plain \\
\hline & body & b-g & G & - & 7.6 & plain \\
\hline \multirow[t]{7}{*}{$127 / 98-54$} & body & $\mathrm{g}$ & $\mathrm{A}$ & E SM & 5.8 & $\begin{array}{l}\text { horizontal and vertical } \\
\text { incised lines }\end{array}$ \\
\hline & body & g & $\mathrm{A}$ & - & 6.5 & $\begin{array}{l}\text { cross-hatched incised } \\
\text { lines }\end{array}$ \\
\hline & body & g-h & $\mathrm{F}$ & E SM & 6.6 & $\begin{array}{l}\text { cane punctated-filled } \\
\text { incised zone }\end{array}$ \\
\hline & body & $\mathrm{g}$ & A & - & 5.9 & plain \\
\hline & body & $\mathrm{g}$ & G & $\mathrm{I} / \mathrm{E} \mathrm{SM}$ & 7.9 & plain \\
\hline & body & $\mathrm{g}$ & $\mathrm{H}$ & - & 7.2 & plain \\
\hline & body & $\mathrm{g}$ & G & - & 7.3 & plain \\
\hline \multirow[t]{2}{*}{$128 / 98-54$} & body & $\mathrm{g}$ & $\mathrm{D}$ & - & 7.5 & plain \\
\hline & base & g-b & G & - & 12.7 & plain \\
\hline \multirow[t]{3}{*}{$129 / 98-54$} & body & $\mathrm{g}$ & $\mathrm{F}$ & I SM & 7.7 & parallel incised lines \\
\hline & $\operatorname{rim}(\mathrm{D}-\mathrm{FL})$ & g-b & $\mathrm{C}$ & - & 7.0 & $\begin{array}{l}\text { cross-hatched incised } \\
\text { lines }\end{array}$ \\
\hline & base & $\mathrm{g}$ & $\mathrm{F}$ & - & 9.7 & plain \\
\hline \multirow[t]{13}{*}{ 130/98-54, lv. 4} & body & g-o & $\mathrm{F}$ & I/E SM & 5.3 & $\begin{array}{l}\text { single straight engraved } \\
\text { line; int./ext. red-slipped }\end{array}$ \\
\hline & body & g-o & $\mathrm{F}$ & I/E SM & 5.1 & int./ext. red-slipped \\
\hline & body & $\mathrm{g}$ & $\mathrm{F}$ & - & 6.2 & $\begin{array}{l}\text { curvilinear appliqued } \\
\text { ridges }\end{array}$ \\
\hline & body, CB & g-o & $\mathrm{B}$ & I/E SM & 7.3 & $\begin{array}{l}\text { diagonal-horizontal } \\
\text { engraved lines; int./ext. } \\
\text { red-slipped }\end{array}$ \\
\hline & $\operatorname{rim}(\mathrm{D}-\mathrm{Ro})$ & $g-b$ & $\mathrm{~F}$ & - & 6.3 & cross-hatched incised lines \\
\hline & rim (D-Ro) & g & G & I SM & 8.2 & cross-hatched incised lines \\
\hline & $\begin{array}{l}\operatorname{rim}(D-R o \\
\text { ext f) }\end{array}$ & $\mathrm{g}$ & $\mathrm{B}$ & E SM & 6.8 & $\begin{array}{l}\text { horizontal engraved line; } \\
\text { int./ext. red-slipped }\end{array}$ \\
\hline & $\begin{array}{l}\text { rim }(D-R o \\
\text { ext f, } 27 \mathrm{~cm} \\
\text { OD) }\end{array}$ & g & B & $\begin{array}{l}\text { E B/ } \\
\text { I SM }\end{array}$ & 6.0 & $\begin{array}{l}\text { horizontal engraved line; } \\
\text { int./ext. red-slipped }\end{array}$ \\
\hline & base & $\mathrm{g}$ & $\mathrm{F}$ & - & 9.6 & plain \\
\hline & body & $\mathrm{g}$ & G & - & 6.6 & plain \\
\hline & body & $\mathrm{g}$ & A & E SM & 6.5 & plain \\
\hline & body & $\mathrm{g}$ & $\mathrm{E}$ & I SM & 7.0 & plain \\
\hline & body & g-b & $\mathrm{C}$ & E SM & 9.0 & plain \\
\hline
\end{tabular}


Appendix 1, Detailed Analysis of Decorated and Plain Sherds from 41LR351, cont'd.

\begin{tabular}{|c|c|c|c|c|c|c|}
\hline $\begin{array}{l}\text { Lot/Provenience } \\
(\mathrm{N}-\mathrm{E})\end{array}$ & Sherd type & Temper & FC & ST & $\begin{array}{l}\text { Th } \\
(\mathrm{mm})\end{array}$ & Decoration \\
\hline 133/97-60 & body, CB & g & A & E SM & 7.2 & plain \\
\hline \multirow[t]{4}{*}{$134 / 99-54$} & body & $\mathrm{g}$ & G & - & 6.5 & $\begin{array}{l}\text { cross-hatched engraved } \\
\text { lines }\end{array}$ \\
\hline & rim, CB (D-Ro) & g & $\mathrm{F}$ & $\mathrm{I} / \mathrm{E} \mathrm{SM}$ & 6.5 & $\begin{array}{l}\text { horizontal and opposed } \\
\text { diagonal engraved lines }\end{array}$ \\
\hline & body & g-o & G & E SM & 9.2 & plain \\
\hline & base & $g-b$ & G & $\mathrm{I} / \mathrm{E} \mathrm{SM}$ & 10.6 & plain \\
\hline \multirow[t]{9}{*}{ 135/99-54, lv. 1} & body & g & B & $\begin{array}{l}\text { E B/ } \\
\text { I SM }\end{array}$ & 5.5 & $\begin{array}{l}\text { horizontal engraved line; } \\
\text { int./ext. red-slipped }\end{array}$ \\
\hline & body & $\mathrm{g}$ & B & I/E SM & 5.1 & int./ext. red-slipped \\
\hline & body & g & B & $\mathrm{I} / \mathrm{E} \mathrm{SM}$ & 4.8 & $\begin{array}{l}\text { single straight engraved } \\
\text { line; int./ext. red-slipped }\end{array}$ \\
\hline & $\begin{array}{l}\text { rim (D-Ro, } \\
+15 \mathrm{~cm} \text { OD) }\end{array}$ & g-b-h & $\mathrm{F}$ & - & 9.7 & free tool punctates \\
\hline & body & $\mathrm{g}$ & $\mathrm{F}$ & - & 6.2 & parallel engraved lines \\
\hline & body & g & G & - & 6.3 & plain \\
\hline & body & g & $X$ & - & 7.7 & plain \\
\hline & body & g & $\mathrm{F}$ & E SM & 7.0 & plain \\
\hline & body & g & $\mathrm{F}$ & - & 7.9 & plain \\
\hline \multirow[t]{3}{*}{ 136/98-59, lv. 7} & body & $\mathrm{g}$ & $\mathrm{B}$ & - & 9.2 & parallel incised lines \\
\hline & body & $\mathrm{g}$ & $\mathrm{E}$ & - & 7.7 & plain \\
\hline & body & $\mathrm{g} / \mathrm{SP}$ & A & - & 6.9 & plain \\
\hline \multirow[t]{8}{*}{ 137/98-54, lv. 6} & body & $\mathrm{g}$ & $\mathrm{H}$ & - & 7.3 & cane punctated rows \\
\hline & body & $g-b$ & G & I/E SM & 7.7 & int./ext. red-slipped \\
\hline & body & $\mathrm{g}$ & G & - & 8.8 & $\begin{array}{l}\text { vertical and diagonal } \\
\text { engraved lines }\end{array}$ \\
\hline & rim & $\mathrm{g}$ & A & - & 5.9 & plain \\
\hline & $\begin{array}{l}\operatorname{rim}, \mathrm{CB} \\
(+13 \mathrm{~cm} \mathrm{OD})\end{array}$ & $\mathrm{b}$ & A & - & 6.0 & plain \\
\hline & body & $\mathrm{g} / \mathrm{SP}$ & $\mathrm{K}$ & - & 6.9 & plain \\
\hline & body & $\mathrm{g}$ & B & - & 6.4 & plain \\
\hline & base & g & $\mathrm{F}$ & - & 11.0 & plain \\
\hline \multirow[t]{5}{*}{ 138/100-52, lv. 6} & $\operatorname{rim}(\mathrm{D}-\mathrm{Ro})$ & $\mathrm{g}$ & $\mathrm{F}$ & - & 6.3 & $\begin{array}{l}\text { opposed diagonal } \\
\text { engraved lines }\end{array}$ \\
\hline & $\operatorname{rim}(\mathrm{D}-\mathrm{Ro})$ & $\mathrm{g}$ & G & I SM & 8.8 & plain \\
\hline & body & g & G & - & 6.3 & plain \\
\hline & body & g-h & $\mathrm{F}$ & - & 5.2 & plain \\
\hline & body & $\mathrm{g}$ & G & E SM & 5.4 & plain \\
\hline \multirow[t]{2}{*}{$139 / 100-51$} & body & g & A & I/E SM & 5.6 & plain \\
\hline & body & g-h & A & - & 6.0 & plain \\
\hline
\end{tabular}


Appendix 1, Detailed Analysis of Decorated and Plain Sherds from 41LR351, cont'd.

\begin{tabular}{|c|c|c|c|c|c|c|}
\hline $\begin{array}{l}\text { Lot/Provenience } \\
(\mathrm{N}-\mathrm{E})\end{array}$ & Sherd type & Temper & $\mathrm{FC}$ & ST & $\begin{array}{l}\text { Th } \\
(\mathrm{mm})\end{array}$ & Decoration \\
\hline 139/100-51, cont'd. & body & $\mathrm{b}-\mathrm{h} / \mathrm{SP}$ & $\mathrm{E}$ & I SM & 7.4 & plain \\
\hline \multirow[t]{3}{*}{ 140/100-51 } & body & $\mathrm{g}$ & G & E SM & 5.4 & $\begin{array}{l}\text { horizontal engraved line; } \\
\text { int./ext. red-slipped }\end{array}$ \\
\hline & body & $\mathrm{g}$ & $\mathrm{E}$ & - & 8.4 & plain \\
\hline & body & $\mathrm{b}$ & $\mathrm{F}$ & I/E SM & 7.2 & plain \\
\hline \multirow[t]{6}{*}{ 141/100-51, lv. 7} & $\operatorname{rim}(\mathrm{D}-\mathrm{FL})$ & $g-b$ & $\mathrm{~B}$ & I SM & 6.2 & diagonal incised lines \\
\hline & $\begin{array}{l}\text { rim (D-Ro), } \\
\text { Bottle, } 4 \mathrm{~cm} \\
\text { OD }\end{array}$ & g & $\mathrm{F}$ & - & 7.5 & plain \\
\hline & base & g-h & $\mathrm{F}$ & - & 12.5 & plain \\
\hline & base & $\mathrm{g}$ & $\mathrm{H}$ & - & 11.6 & plain \\
\hline & body & $\mathrm{g}$ & $\mathrm{F}$ & - & 8.7 & plain \\
\hline & body & $\mathrm{g}$ & $\mathrm{A}$ & I SM & 7.5 & plain \\
\hline \multirow[t]{2}{*}{$144 / 98-59$} & $\begin{array}{l}\operatorname{rim}(D-R o \\
\text { ext f) }\end{array}$ & $\mathrm{g}$ & $\mathrm{B}$ & E SM & 6.6 & $\begin{array}{l}\text { horizontal engraved lines; } \\
\text { int./ext. red-slipped }\end{array}$ \\
\hline & $\begin{array}{l}\operatorname{rim}(D-R o \\
\operatorname{ext} f)\end{array}$ & g & $\mathrm{H}$ & - & 7.9 & $\begin{array}{l}\text { horizontal and vertical } \\
\text { engraved lines }\end{array}$ \\
\hline $145 / 98-59$ & body & $\mathrm{b}$ & $\mathrm{F}$ & I SM & 4.2 & cross-hatched incised lines \\
\hline $146 / 98-59$ & body & $\mathrm{g}$ & $\mathrm{A}$ & E SM & 8.0 & plain \\
\hline \multirow[t]{3}{*}{ 147/98-59, lv. 6} & body & $\mathrm{g}$ & $\mathrm{B}$ & E SM & 5.7 & int./ext. red-slipped \\
\hline & body & g & $\mathrm{F}$ & - & 8.0 & plain \\
\hline & body & $\mathrm{g}$ & $\mathrm{F}$ & I/E SM & 7.3 & plain \\
\hline $148 / 98-59$ & body & $\mathrm{g}$ & $\mathrm{B}$ & E SM & 7.9 & plain \\
\hline $149 / 99-54$ & body & $\mathrm{g}$ & $\mathrm{F}$ & - & 7.9 & plain \\
\hline \multirow[t]{8}{*}{ 150/99-54, lv. 5} & rim & $\mathrm{g}$ & $\mathrm{B}$ & I SM & 8.1 & cane punctated rows \\
\hline & body & $\mathrm{g}$ & $\mathrm{B}$ & - & 8.4 & $\begin{array}{l}\text { tool punctate-filled incised } \\
\text { triangle }\end{array}$ \\
\hline & body & g & G & E SM & 6.0 & $\begin{array}{l}\text { cane punctate-filled } \\
\text { incised zone }\end{array}$ \\
\hline & $\operatorname{rim}(\mathrm{D}-\mathrm{Ro})$ & g & $\mathrm{G}$ & - & 6.2 & diagonal incised lines \\
\hline & $\operatorname{rim}(\mathrm{D}-\mathrm{Ro})$ & g-h & $\mathrm{F}$ & - & 7.3 & diagonal incised lines \\
\hline & body & g & $\mathrm{G}$ & - & 7.2 & plain \\
\hline & body & $\mathrm{g}$ & $\mathrm{E}$ & - & 8.7 & plain \\
\hline & body & $\mathrm{g}$ & $\mathrm{H}$ & - & 8.7 & plain \\
\hline \multirow[t]{2}{*}{ 151/100-57, lv. 4} & body & g & $\mathrm{E}$ & I SM & 6.6 & plain \\
\hline & base & $\mathrm{g}$ & $\mathrm{F}$ & - & 10.3 & plain \\
\hline
\end{tabular}


Appendix 1, Detailed Analysis of Decorated and Plain Sherds from 41LR351, cont'd.

\begin{tabular}{|c|c|c|c|c|c|c|}
\hline $\begin{array}{l}\text { Lot/Provenience } \\
(\mathrm{N}-\mathrm{E})\end{array}$ & Sherd type & Temper & $\mathrm{FC}$ & $\mathrm{ST}$ & $\begin{array}{l}\text { Th } \\
(\mathrm{mm})\end{array}$ & Decoration \\
\hline \multirow[t]{4}{*}{ 152/100-52, lv. 7} & $\operatorname{rim}(\mathrm{D}-\mathrm{Ro})$ & $\mathrm{g}$ & G & - & 9.0 & cross-hatched incised lines \\
\hline & body & g-b & G & - & 9.6 & plain \\
\hline & body & g & $\mathrm{F}$ & E SM & 7.2 & plain \\
\hline & body & $\mathrm{g} / \mathrm{SP}$ & G & - & 8.1 & plain \\
\hline 153/95-55, lv. 1 & body & $\mathrm{g}$ & $\mathrm{F}$ & - & 7.1 & plain \\
\hline 155/95-55, lv. 3 & body & $\mathrm{g}$ & A & I SM & 5.4 & plain \\
\hline \multirow[t]{5}{*}{ 156/95-55, lv. 4} & body, Bottle & $\mathrm{g}$ & $\mathrm{B}$ & - & 5.1 & ext. red-slipped \\
\hline & body & g-b-h & $\mathrm{K}$ & - & 9.0 & free fingernail punctated \\
\hline & body & $\mathrm{g}$ & $\mathrm{B}$ & I B & 5.6 & plain \\
\hline & body & $\mathrm{g} / \mathrm{SP}$ & $\mathrm{F}$ & I/E SM & 7.2 & plain \\
\hline & body & g-b-h & $\mathrm{F}$ & - & 7.6 & plain \\
\hline 157/95-55, lv. 5 & base & $\mathrm{g}$ & $\mathrm{F}$ & - & 10.2 & plain \\
\hline \multirow[t]{3}{*}{ 158/95-55, lv. 6} & $\operatorname{rim}(\mathrm{D}-\mathrm{Ro})$ & $\mathrm{g}$ & $\mathrm{F}$ & I SM & 5.1 & cross-hatched incised lines \\
\hline & body & $\mathrm{b}$ & $\mathrm{F}$ & - & 8.4 & plain \\
\hline & body & $\mathrm{g}$ & G & E SM & 7.2 & plain \\
\hline \multirow[t]{5}{*}{ 159/95-55, lv. 7} & body & $\mathrm{g}$ & $\mathrm{C}$ & - & 7.0 & parallel incised lines \\
\hline & $\operatorname{rim}(\mathrm{D}-\mathrm{Ro})$ & g & $\mathrm{E}$ & - & 6.2 & cross-hatched incised lines \\
\hline & body & $\mathrm{g}$ & $\mathrm{C}$ & E SM & 7.9 & plain \\
\hline & body & g & $\mathrm{C}$ & - & 6.8 & plain \\
\hline & body & $\mathrm{g}$ & G & - & 7.6 & plain \\
\hline \multirow[t]{3}{*}{ 160/95-55, lv. 8} & $\operatorname{rim}(\mathrm{D}-\mathrm{FL})$ & g-b & $\mathrm{B}$ & I SM & 7.1 & $\begin{array}{l}2+\text { fingernail punctated } \\
\text { rows }\end{array}$ \\
\hline & body & g & $\mathrm{A}$ & E SM & 7.4 & plain \\
\hline & body & $\mathrm{g}$ & $\mathrm{F}$ & - & 6.8 & plain \\
\hline \multirow[t]{2}{*}{ 161/95-55, lv. 9} & base & $\mathrm{g}$ & $\mathrm{F}$ & - & 9.5 & plain \\
\hline & body & g-b & $\mathrm{F}$ & - & 8.4 & plain \\
\hline 164/96-55, lv. 2 & body & g & A & - & 6.2 & plain \\
\hline \multirow[t]{3}{*}{$165 / 96-55$, lv. 3} & $\begin{array}{l}\text { rim (D-Ro, } \\
\text { ext f) }\end{array}$ & $\mathrm{g}$ & $\mathrm{A}$ & I/E SM & 6.7 & plain \\
\hline & body & $\mathrm{g}$ & $\mathrm{K}$ & - & 8.8 & plain \\
\hline & body & $\mathrm{g}$ & $\mathrm{C}$ & - & 7.1 & plain \\
\hline
\end{tabular}

*Rim Form: D=direct; INV=inverted; EV=everted; Lip: Ro=rounded; FL=flat; ext f=exterior folded Temper: $\mathrm{b}=$ bone; $\mathrm{g}=$ grog; $\mathrm{h}=$ hematite; $\mathrm{o}=$ organics; $\mathrm{SP}=$ sandy paste

FC=firing conditions, follow Teltser (1993:Figure 2) and Perttula (2005:Figure 5-30); X=multiple oxidized and reduced bands in the sherd cross-section $\mathrm{ST}=$ surface treatment; $\mathrm{E}=$ exterior; $\mathrm{I}=$ interior; $\mathrm{SM}=$ smoothed; $\mathrm{B}=$ burnished $\mathrm{Th}=$ thickness; $\mathrm{OD}=$ orifice diameter; $\mathrm{CB}=$ carinated bowl 